\title{
Yükseköğretim Kurumlarında Bilimsel Araştırma Destekleri
}

\author{
İsmail Erol \\ Yusuf Alpaydın
}

\begin{abstract}
Öz: Bu araştırmanın amacı, yükseköğretim kurumlarının akademisyenlere sağladığı bilimsel araştırma desteklerinin (BAP) belirli kriterler açısından incelenmesidir. Araştırmada betimsel tarama yöntemi ve içerik analizi tekniği kullanılmıştır. Türkiye'de 2000 yılı öncesinde kurulan 73 üniversite, araştırmanın evrenini oluşturmaktadır. Araştırmanın örneklemine BAP verilerine ulaşılabilen 30 üniversite dâhil edilmiştir. Bulgularına bakıldığında, BAP birimlerinin faaliyet raporlarına ulaşım kolayca sağlanmaktadır. Proje türü sayılarına baktığımızda 2 ile 15 arasında değişim gösterdiğini görmekteyiz. Desteklenen proje türlerine baktığımızda; Lisansüstü tez projeleri, Bilimsel AR-GE için altyapı destek projeleri, Hızlı destek araştırma projeleri, Bilimsel etkinliklere katılım ve düzenleme desteği projeleri ile yoğun olarak karşılaşılmaktadır. Araştırmada üniversitelerin BAP desteği başvurularını çevrimiçi ortamda kabul ettiği ve yüksek oranla yılın her anında başvuru kabul edilebildiği ortaya çıkmıştır. Harcama kalemlerinde ise, hizmet alım giderleri, seyahat giderleri, bilgisayar ve onarım giderleri ile karşılaşılmaktadır. BAP proje sürelerine bakıldığında genellikle 12-24 ay sürdüğü ve sonuç raporlarının istendiği görülmektedir. Destek sayısı limitleri 1-3 aralığında değişmektedir. Araştırma sonuçlarında; yükseköğretim kurumlarının akademisyenleri bilimsel araştırma projelerine teşvik ettiğini, başvuruları online olarak kabul ettiğini ve bunları komisyonlarca karara bağladığını görmekteyiz. Nitekim proje destek sayılarındaki limit akademisyenleri yılda bir veyahut iki yılda bir tek proje yapmaya yönlendirmektedir.
\end{abstract}

Anahtar Kelimeler: Yükseköğretim Kurumları, BAP Birimleri, Bilimsel Araştırma Destekleri.

\begin{abstract}
The purpose of this research is to examine the scientific research support (BAP) provided by academicians for the purpose of certain criteria. Descriptive screening model and content analysis technique were used in the study. The study's universe was 73 universities all of which were established before 2000. The study's sample included 30 universities accessible to BAP data. According to their findings, access to the activity reports of BAP units was easily achieved. When we look at the project type numbers, we see that it varies from 2 to 15 . When we look at the types of supported projects; Supranational thesis projects, Infrastructure support projects for scientific research, Rapid support research projects, Participation and regulatory support projects for scientific activities are intensively encountered. The study found that universities accepted BAP support applications online and were able to accept applications at a high rate every year. In expenditure items, service purchase expenses, travel expenses, computer and staff expenses are encountered. When the BAP project duration is examined, it usually takes 12 to 24 months and results reports are requested. The support number limits range from 1-3. In the research results; we see that higher education institutions encourage academicians to scientific research projects, accept applications online and link them to commissions. Thus; the limit on the number of project supports leads the academicians to make one project every year or every two years.
\end{abstract}

Keywords: Higher Education Institutions, BAP Units, Scientific Research Supports. 


\section{Giriş}

Bilimde gelişme, araştırma ve buluş çağı olarak nitelendirdiğimiz zaman diliminde, eğitim dünyasındaki gelişmelerle yükseköğretim alanında gerçekleşen bilimsel çalışmaların, araştırmaların ve projelerin kalitesi, içeriği ve kapsamları yeniden gözden geçirilmektedir. Dünyanın hızlı bir şekilde küreselleşmesi, bireylerin bilgiye kolay ulaşması ve tüm dünyada bilimsel doğruların kolayca paylaşılması, araştırmaların daha kapsamlı yapılmasına, nitelik ve nicelik kazanmasına yardımc1 olmuştur. Böylece akademisyenlerin yükseköğretim kurumlarında daha kaliteli ve daha nitelikli bilimsel araştırmalar için kaynak, bütçe ve finansal destek bulma arayışları çeşitlenmiştir.

Uygarlık ve toplumların gelişmesi, bilim ve sanat alanlarında ilerleme kat etmelerine bağlıdır. Yücel (1997)'e göre, günümüzde güçlü olarak tabir ettiğimiz ülkelerin bilim ve sanatta söz sahibi ülkeler olması rastlantı değildir. Bu durumun farkına varan toplumlar ve milletler, bilim alanında araştırma ve geliştirme çalışmalarına büyük önem vermekte ve bu akademik çalışmalara yüksek bütçe ve zamanlar ayırmaktadirlar.

1970’li yılların sonuna doğru dünyamızda değişime uğrayan ekonomi sistemiyle devletlerin kamusal alandaki harcamaları azalmış ve rekabet artarak özel girişimler çoğalmıştır. Bu durum da üniversitelerin, eğitim için ayrılan fonlara ihtiyacını bir hayli çoğaltmış ve bu fonlardan daha fazla yararlanılması adına onları performanslarını sürekli artırmaya yöneltmiştir (Ak \& Gülmez, 2006). Bu sebeple kamu ve araştırma fonlarının pay edilmesi büyük oranda kurumların ve araştırmacıların bilimsel yayın/araştırma performanslarına bağlanmıştır (Yükseköğretim Kurulu, 2003).

Uluslararası akademik proje başvurularında olduğu gibi, Türkiye'de de bilimsel araştırma projeleri (BAP), yükseköğretim kurumunun uzman elemanı bulunan her dalda, ulusal bilim ve teknoloji politikaları, milletin ve ülkenin hedeflerine ya da yükseköğretim kurumlarının belirlediği bilim politikalarına uygun olan projelere öncelik verilip seçilmektedir. BAP Projelerinin teknolojik, ekonomik, sanatsal, sosyal, kültürel politikaların ve araştırma politikalarının gelişimine katkı sağlaması esastır.

\section{Dünyada ve Türkiye' de Bilimsel Araştırma Politikaları}

Yıldırım (1997) açıklamalarında, içinde bulunduğumuz son yıllarda teknoloji, ekonomi ve bunlara dayalı olarak bilimde ilerlemenin sadece bu faaliyetlere ayrilan zaman ve bütçe ile mümkün olmayacağını dile getirmiştir. Belli politikalar ile düzenli ve takvimli bir çalışma ile bilimsel araştırmalar sonuca ulaşabilir. Dünyada örnekle- 
rini gördüğümüz bilimsel araştırma projelerinde teknoloji ve ekonomi temelli ülke gelişimine katkı sağlamaları esastır. Proje başvuruları ilgili kurumlara, projelerin gerekçeleri, yöntemleri, sağlayacağı özgün değerler, ulusal ve uluslararası bağlamda sağlayacağı katkı, çalışma çizelgesi ve bütçe dökümlerinin yer aldığı proje başvuru formları ile yapılmaktadır.

OECD verilerine göre, 2008 yılı itibariyle çeşitli ülkelerde AR-GE harcamalarının finans kaynağına ve gerçekleştiren sektörlere göre dağılımı verilmektedir. Dağılıma göre; özellikle gelişmiş ülkeler olarak adlandırdığımız ABD, Japonya, Çin, Almanya, İngiltere ve Fransa gibi ülkelerde özel sektörün gerek AR-GE harcamalar1nın finansmanında, gerekse de gerçekleştiren sektörler bazında önemli bir payının olduğu görülmektedir. OECD ve AB toplamında da özel sektörün toplam AR-GE faaliyetleri içerisindeki payı kamuya oranla daha yüksek gerçekleşmiştir. Gelişmekte olan ülkeler grubunda adlandırdığımız Yunanistan, Türkiye, Polonya, Yeni Zelanda gibi ülkelerde ise kamunun ve özellikle de yükseköğretimin AR-GE faaliyetlerine katılımının yüksek olduğu görülmektedir (OECD, 2010).

Üniversitelerde sürdürülen bilimsel araştırmalar ise üniversitelerin hazine gelirleri içerisinde yer alan bilimsel araştırma ödenekleri ve üniversitelerin döner sermaye gelirlerinden bilimsel araştırmalara ayrılan ödeneklerle finanse edilmektedir. Bu bağlamda, bir ülkenin genel olarak bilimsel araştırma harcamaları ve özel olarak temel bilimsel araştırmaların en yoğun yapıldığı kurumların başında gelen üniversitelerin bütçeleri içerisinde araştırma projeleri ödeneklerinin yeterli düzeyde olması, bilimsel araştırmaların yapılabilmesi ve elde edilen sonuçlarla toplumsal ve ekonomik gelişmenin sağlanması açısından son derece önem kazanmaktadır (Boz, 2011).

Türkiye'de, bilim, teknoloji ve yenilik politika önerilerini oluşturma ve mevcut politikaların gerçekleştirilmesine yönelik araç ve yöntemleri belirleme faaliyetleri, Bilimsel ve Teknolojik Araştırma Kurumu (TÜBİTAK) bünyesi altında bulunan Bilim, Teknoloji ve Yenilik Politikaları Daire Başkanlığı vasıtasıyla gerçekleştirilmektedir. Bu anlamda TÜBİTAK, ülke yöneticilerine Türkiye'nin bilim, teknoloji ve yenilik politikalarının ortaya çıkarılmasında danışman görevi üstlenmektedir (BTYPD Yönetmeliği, 2012).

\section{Türkiye'de Bilimsel Araştırmalarda Nitelik ve Araştırma Alanlarının Yoğunluğu}

Bilim ve teknoloji alanında başarı sağlamanın önemli hususlarından biri de ülkede var olan araştırmacıların yani bilim insanlarının nitelikleri, sayıları ve araştırma alanlarıdır. Uluslararası düzeyde yayım sayıları, ülkede bilim üzerine çalışmalar yapan insanların niteliğini açığa çıkarırken, toplam araştırmacı sayısı ve AR-GE 
çalışanı kadrosunda görev yapanların niteliği de ülkenin bilim ve bilimsel çalışmalara yaklaşımını ortaya çıkarır (TÜBİTAK, 2016). Türkiye'de, 1998-2008 yılları arasında 10.000 çalışan kişi başına düşen araştırmacı sayısı 1998 yılında 8,7 civarı iken, 2003 yılında hızlı bir şekilde yükselişe geçmiş, önce 15,4'e sonrasında ise 24,9 oranlarına kadar yükselmiştir. AR-GE çalışanı sayımıza bakıldığında da paralel bir yükselme gerçekleşmekte, 2008 yllında 10.000 çalışan kişi başına düşen AR-GE çalışanı sayısı 31,7 oranlarına yükselmiştir (TÜBİTAK, 2016).

Türkiye'deki araştırmacılar, teknoloji, bilim alanlarına göre incelendiği zaman, teknoloji ile uğraşan bilimlerin \%39 oranla en fazla araştırmacı yoğunluğuna sahip olduğu ortaya çlkmaktadır. Teknoloji ile uğraşan bilimleri \%18 gibi bir oranla "sosyal bilimler" ve "matematik, fizik, astronomi ve yaşam bilimleri" takip etmektedir. Tarımsal bilimler ise \%10 ile en az yoğunluğa sahip olmuştur. Sağlık bilimleri ile ilgilenen araştırmacılar ise toplam sayı oranı içinde \%15 oranla temsil edilmektedir (TÜBİTAK, 2016).

\section{Türkiye'deki Üniversitelerin Durumu ve Bilimsel Araştırma Politikaları}

Yükseköğretim hizmeti veren üniversiteleri geniş bir tanım ile ifade edilecek olursak, toplumda ihtiyaç duyulan insan gücü gereksinimi, kültürün gelecek nesillere aktarılma ihtiyacı ve bilimsel araştırma yolları ile toplumdaki sorunların çözülmesine destek olma misyonunu üstlenen kuruluşlar olarak kabul edilir (Başkan, 2001). Üniversiteler, toplumun her alanında halkla iç içe, eğitim sistemimizin de en üst kısmında bulunmaktadır. Eğitim sisteminin diğer basamaklarının başlıca görevleri arasında "hazır bilgiyi aktarmak" olarak ifade edilirken, yükseköğretim kurumları ise ana işlev olarak "bilgi üreticisi, yayıcısı ve bilginin kullanımını sağlayan kurum” olarak görev yapmaktadır (Tuzcu, 2003). Üniversiteler, aklın ve fikrin nitelendirildiği yerlerdir. Üniversitelerde tüm alanlardan önce bilim yapılmalıdır. Bazı problem durumlarının ortaya konması, bazı hipotezlerin öne çıkarılması ve bunların denenmesi araştırmalar kapsamında devam ettirilir. Bilim sürekli devam eden araştırmalar bütünüdür. Bilim keşif işidir. Bilineni başkasına aktarmak ya da anlatmak bilim olarak adlandırılamaz. Araştırmalar ve çalışmalar sonunda çözüm ve sonuçlar elde edilirse bilim yapilmış olacaktır (Gasset, 2014). Farklı bir bakış açısı ile Günay'ın (2001) tanımıyla üniversiteler; eğitim hizmeti verdiği programlar vasıtası ile ülkenin ihtiyacı olan uluslararası boyutta hizmet verebilecek insanlar yetiştiren, uluslararası bağlamda araştırma, geliştirme ve yenilik faaliyetleri yapan kuruluşlardır. Aynı zamanda bilim, bilimsel çalışmalar ve teknolojik imkânlar geliştiren, yerel ve dünya çapında yayımlar gerçekleştiren, içinde bulunduğu toplumun yaşadığı sorunlara destek olabilen, farklı birimlerden meydana gelen, özerk, özgür olan, etkili ve yetkili bir yükseköğretim kuruluşudur. 
Türkiye'de, gelişmekte olan ekonomi sistemleriyle birlikte artan bilimsel yayın ve araştırma faaliyetlerinin büyük bir kısmı üniversitelerde gerçekleştirilmektedir. Moed (2006b) da gerçekleştirdiği araştırma ile Türkiye'deki yükseköğretim kurumları, ülkedeki bilimsel yayınların \%91'ini ortaya çıkarmakta ve bu oran ile Türkiye, Avrupa'da ilk sirada yer almaktadır.

Gelişen teknoloji ve bilimsel imkânlar ile birlikte araştırma alanları da genişlemiş, farklı ilgi alanları, farklı tip projeler ve çeşitli çalışma alanları ortaya çıkmıştır. Bu projeleri, bilimsel araştırmaları ve çalışmaları yürütmek zaman zaman maddi unsurlar göz önüne geldiğinde kolay gerçekleşmemektedir. Bu süreçlerde, yükseköğretim kurumlarındaki bilimsel araştırma desteklerinin önemi bir kez daha gün yüzüne çıkmaktadır. Bilimsel araştırmaların ve projelerin, gerçekleştirildiği topluma katkı sağlaması, bilime ışı tutması, gelecek nesilleri aydınlatması ve bir sonuca bağlanması beklenir. Yükseköğretim kurumları da bu tür proje, çalışma ve araştırmaları gerçekleştiren akademisyenleri bünyesinde bulundurmak ister. Bu akademisyenlere bilimsel araştırmalarında, çalışmalarında ve projelerinde maddi destek verir. Bilimsel araştırmaların önemli bir finans kaynağı BAP yani bilimsel araştırma projeleridir. BAP projeleri araştırma desteklerinin içeriğinin, geçerliliğinin ve kapsamının incelenmesi, projelerin hangi şartlarda ne gibi desteklerle yapıldığının araştırılması ve projelerin birer sonuca bağlanması ve değerlendirilmesi de ayrı bir önem arz etmektedir.

\section{Yükseköğretim Kurumlarında "Bilimsel Araştırma Projeleri”}

Bilim ve bilimsel çalışmalar icra etmenin toplumumuza ve globalleşen dünyada tüm uluslara katkısı büyüktür. Yükseköğretim kurumları, akademisyenlerin bilimsel araştırma ve çalışmalarına "Bilimsel Araştırma Projeleri" kısa adıyla BAP ile destek olmaktadırlar. Projenin tanımına baktığımızda "zaman kavramının, kaynakların kısıtlılığı ve bütçe imkânlarının sinırlılığı göz önünde bulundurularak, bir sonuca varılmak üzere gerçekleştirilen geçici süreçler bütünüdür” (Shenhar, 2004, s. 570). BAP projeleri dendiğinde akıllara ilk olarak evrensel ve toplumsal düzeyde; bilim, ekonomi, sanat alanlarına katkı sağlayacak pratik ya da teorik projeler gelmektedir. Türkiye'de her yükseköğretim kuruluşu bünyesinde BAP projelerini yürüteni takip eden ve kabulü ile değerlendirmesini yapan bir birim bulundurmaktadır. Sadeleştirilmiş adı ile BAP (Bilimsel Araştırma Projeleri), üniversitelerdeki bilimsel çalışmaların ve araştırmaların desteklenmesi için gerçekleştirilen bir uygulamadır. Bilimsel araştırma projeleri, Yükseköğretim Kurulu'nun (YÖK) 01.01.2002 tarihinde yürürlüğe soktuğu Yükseköğretim Kurumları Bilimsel Araştırma Projeleri Hakkında Yönetmelik kapsamında desteklenmektedir (Anadolu Üniversitesi, 2017). 
Yükseköğretim kurumlarında "Bilimsel Araştırma Projeleri” yönetmelikler ile güvence altına alınmıştır. Bilimsel araştırma projeleri ile ilgili yönetmeliğin amaç ve kapsamı, yükseköğretim kurumlarında yürütülen bilimsel araştırma proje tekliflerinin değerlendirilmesi, kabulü, desteklenmesi, bunlara ilişkin hizmetlerin yürütülmesi, izlenmesi, sonuçlarının değerlendirilmesi, kamuoyuna duyurulması ve ilgili usul ve esaslar ile diğer hususları belirlemektir (Resmi Gazete, 2016). Bilimsel araştırma projeleri ile ilgili yönetmeliğin tanımlar ve kısaltmalarında önemli görülenler şunlardır (Resmi Gazete, 2016):

- Araştırmac1

- Bilimsel Araştırma Projesi

- Bilimsel Araştırma Projeleri Koordinasyon Birimi Koordinatörü

Bilindiği üzere özellikle 2011 yılı sonrası Türkiye'de sanayi, ekonomi ve akademik çalışmalarda teknoloji geliştirme, araştırma ve yenilik süreçlerinde önemli gelişmelere ve çalışmalara imza atılmıştır. Ülkemiz gelişim politikaları 2023 yılı itibarı ile dünyada 10 öncü ekonomiden biri olma hedefi merkeze alındığı zaman, bu süreçte yükseköğretim odaklı iki önemli strateji, nitelikli bilgi ve nitelikli insan kaynağına yönelik olmalıdır (Yükseköğretim Kurumu, 2016). Bu açıklamalara dayanarak Türkiye'de araştırma ve bilime verilen destek politikalarının güncellenmesi ve geliştirilmesi gerekmekteydi. Yeni YÖK yönetimi ve sistemi ile sorumlulukları altındaki konuları geniş bir çapta değerlendirmek ve takibe almak üzere gerekli konulara düzenleyici kararlar alma hedefi belirlenmiştir. Bu yaklaşım ile tüm paydaşlardan görüş alınarak, üniversitelerde bilimsel araştırmalara verilen destek yani “Üniversitelerin BAP Yönetmeliği” son şekli verilerek yürürlüğe girmiştir. 26 Kasım 2016 tarihinde yürürlüğe giren bu yönetmelikle,

- BAP Koordinasyon birimlerinin görev alanı üniversitelerimizin bütünsel araştırma süreci yönetimi yaklaşımı ile yeniden tanımlanmış ve genişletilmiştir.

- Fikrî mülkiyet ve telif haklarına yönelik olarak dünyadaki ve Türkiye'deki gelişmeler kapsamında düzenlemeler yapılmıştır.

- BAP Komisyonları yetkinliği önceleyen bir yapıya dönüştürülmüştür.

- Rektörün onayına bağlanan sözleşmelerin süreçleri hızlandırılmıştır.

- Proje gelişme raporları ve buna ilişkin düzenlemelerde üniversitelerimize daha fazla yetki verilmiştir.

- Ödenekler ve muhasebe işlemlerine yönelik olarak yıllar içinde değişen düzenlemelere uyumlu hale getirilmiştir. 
Bilimsel Araştırma Projeleri (BAP) için yönetmelikte belirtilen görevlerin yürütülmesi için rektör veya görevlendireceği bir rektör yardımcısı başkanlığında senatonun önerisiyle rektör tarafından görevlendirilen, en az yedi en çok on bir öğretim üyesinden oluşan bir komisyon kurulur. Komisyon üyeleri, yükseköğretim kurumunda var olan bilim dalları arasında denge gözetilmek suretiyle dört yıl için görevlendirilir. Süresi biten üye aynı usulle yeniden görevlendirilebilir. Komisyon üyeleri; görev, yetki ve sorumluluklarını yerine getirmediklerinin tespit edilmesi halinde, senatonun önerisi üzerine rektör tarafından görev süreleri dolmadan görevden alınabilirler. Komisyonun görev, yetki ve sorumlulukları; yükseköğretim kurumunun senatosunca çıkarılacak yönerge ile düzenlenir (Resmi Gazete, 2016). Boğaziçi Üniversitesi Araştırma Birimi (2017) tanımı ile BAP komisyonunun amacı şöyle tanımlanmıştır:

- BAP bütçelerinin projeler temele alınarak araştırma yapacak akademisyenlere destek sağlayacak biçimde dağıtımının yapılması ve araştırmacıların kullanımı için sunulması,

- Üniversite bünyesine yeni dâhil olan öğretim üyelerine başlangıç desteğinde bulunulmas1,

- Proje çağrı takvimlerinin belirlenmesi,

- $\quad$ Proje bütçelerinin üst limitlerinin ve proje bütçe kalemlerine ilişkin üst alım limitlerinin kanunlara bağlı kalarak BAP mali koordinatörlük birimleri ile birlikte belirlenmesinin sağlanması,

- Proje bütçelerinin dağıtımları yapılırken belirli olan miktar ve üst limitlere bağlı kalarak dağıtım yapmak ve yürütülen projelerin raporları ve gelişmelerini takip etme, denetleme ve bu projelerin tüm taleplerini değerlendirip sonuçlandırılmasını sağlama,

- Proje ve araştırma çalışmalarını özendirme ve kariyerlerinin başındaki genç akademisyenleri ödüllendirmek için doktora tez ödülü başvurularını inceleme.

Bilimsel araştırma proje başvurularına sağlanan destekler, proje talep listesi ile BAP komisyonuna iletilir ve bütçe Talep kalemlerinden oluşur (Boğaziçi, 2017). BAP projeleri ve desteklerinin akademisyenlere birden fazla avantajları vardır. Bunlardan birkaçı şunlardır:

- Projeler neticesinde yürütücüler ve araştırmacı ekip puan kazanmaktadırlar. Bu puanları akademik olarak yükselmek ve akademik teşvik için kullanabilirler.

- BAP projeleri vasıtası ile ülkemizin ekonomisi, bilimi ve gelişmesine katkı sağlanmaktadır. Yeni ve daha önceden ortaya çıkarılmamış bilimsel sonuçlara ulaşılır. 
- Bir proje içerisinde bulunup bilim adına faaliyet göstermek ve bir bilimsel gerçekliği ortaya çıkarmak hayatta kazanılacak önemli tecrübeler arasındadır.

- BAP projeleri daha büyük ulusal ve uluslararası bazlı projeler için deneyim merkezidir. Bu projeleri gerçekleştirip deneyim elde eden akademisyenler ve bilim insanları daha büyük projelere imza atabilirler.

- Bilimsel araştırmalar için maddi imkânların el vermediği noktalarda, yeterli teçhizat ve materyalin sağlanması için önemli bir finans kaynağıdır.

\section{Türkiye' deki Bilimsel Araştırma Teşvikleri ve Dağılımları}

Teknoloji ve bilim toplumun sosyal ve ekonomik faaliyetlerinde, gelişmesinde önemli bir role sahipken, söz konusu gelişmeler, yapılan araştırmalar sonucunda kazanılan bilgilerin kullanılması ile ortaya çıkmaktadır. Bilimsel araştırma tanım olarak, bilim insanının bilimsel yöntemleri kullanarak belli bir sorunun çözümüne yanıt arama sürecidir ve bu süreç, araştırma konusu problemin tanımlanması ve çözüme yönelik yöntemlerin uygulanmasını kapsamaktadır. Çözüme yönelik yöntemler, veri toplama sürecinden verilerin değerlendirilmesi ve yorumlanmasına kadar uzanan geniş bir alanda incelenmektedir (TÜBİTAK, 2010).

Bilimsel araştırmalar ve özellikle de temel bilimsel araştırmalar genellikle üniversitelerde ve devlet desteğiyle sürdürülmektedir. 20. yüzyılla birlikte, bilimsel araştırmaların ekonomik ve toplumsal öneminin artması sonucunda, üniversitelerde sürdürülen temel bilimsel araştırmalar, devletler tarafından teşvik edilmeye ve kamu gelirleriyle desteklenmeye başlanmıştır. Bu bağlamda, temel bilimsel araştırmalardan elde edilen sonuçlar evrensel düzeyde insanlık açısından önemli olmakta ve üniversitelerin toplumsal değerini daha da arttırmaktadır (Boz, 2011).

İskender ve İskender'in verilerine göre (2016); TÜBİTAK 2015 yılı içerisinde araştırmacılara 700 milyon TL destekte bulunmuştur. Bu destek miktarının 273 milyonluk kısmı Ankara'daki üniversitelere gitmiştir. Ankara şehri içerisinde 2016 yılı verileri temel alındığında 272.742 öğrenci ve 19.377 öğretim elemanı yaşamaktadır. TÜBİTAK desteklerinden en yüksek ikinci desteği ise İstanbul şehri yaklaşık 112 milyon ile almıştır. 581.954 öğrenci ve 30.128 öğretim elemanı İstanbul'da yaşamaktadır. En fazla üçüncü desteği ise 106 milyon TL ile sanayi şehri olan Kocaeli almıştır. Kocaeli ilinde 78.275 öğrenci ve 2628 öğretim elemanı yaşamaktadır. İzmir ise ikinci sırada yaklaşık olarak 41 milyon TL destek almış ve şehir içinde 159.801 öğrenci, 9722 öğretim elemanı hayatını sürdürmektedir. TÜBİTAK’ın destek aktardığı ilk ondaki diğer iller ise sıra ile Antalya, Kayseri, Konya, Eskişehir, Adana ve Isparta illeridir. Listenin son sırasında ise hiç destek alamayan Hakkâri ve Muş bulunmaktadır. 
BAP bütçesi yükseköğretim kurumları bütçeleri içerisinde yer almaktadır. 2547 sayılı Yükseköğretim Kanununa 25.06.2009 tarihli ve 5917 sayılı Kanunun 21'inci maddesiyle eklenen Ek 28. maddeye dayanılarak hazırlanan (10.07.2009 tarih ve 27284 sayılı Resmi Gazete) "Yükseköğretim Kurumları Bütçelerinde Bilimsel Araştırma Projeleri İçin Tefrik Edilen Ödeneklerin Özel Hesaba Aktarılarak Kullanımı, Muhasebeleştirilmesi ile Özel Hesabın İşleyişine İlişkin Esas ve Usuller" de BAP bütçesine ilişkin esaslara yer verilmektedir. BAP birimlerinin bütçesi içerisinde en önemli kalem hazine gelirlerinden oluşmakta, döner sermaye gelirleri ise üniversitelerin öz gelirlerinin büyüklügüne ve üniversite yönetim kurullarının belirlediği (\%10'dan az olmamak koşuluyla) oranlara göre değişmektedir. Bu iki gelir kaynağının yanı sıra, tezsiz yüksek lisans gelirlerinin \%30’u (2547 sayılı yasanın Ek 27. maddesine göre) yine araştırma projelerinin finansmanında kullanılmaktadır. Bu bağlamda, gerek üniversite bütçelerinin gerek BAP birimlerinin bütçe büyüklükleri, üniversitelerin araştırma potansiyelinin artması ve dolayısıyla da ekonomik ve toplumsal kalkınmanın sağlanması anlamına gelmektedir (Boz, 2011).

Bilimsel araştırma projelerinin ve akademik çalışmaların yükseköğretim kurumlarındaki çalışmalara ve uygulamalara ışık tutması gerekmektedir. Bu sebeple BAP komisyonlarının incelenmesi ve akademisyenlere projeler ile ilgili yol göstermesi önemlidir. Bu yüzden üniversitelerin bilimsel araştırma desteklerinin içeriklerinin tespiti, incelenmesi, değerlendirilip sorgulanması ayrı bir önem arz etmektedir. Bu çalışmanın problem durumunu; yükseköğretim kurumlarındaki bilimsel araştırma desteklerinin içerikleri, faaliyet alanları, bilimsel araştırma desteklerinin kapsamları, başvuru süreleri, proje çeşitliliği ve komisyonların araştırmacılar tarafından tam olarak anlaşılmaması oluşturmaktadır. Türkiye'de yükseköğretim kurumlarında bilimsel araştırma desteklerini tanımlayan ve açıklayan bir çalışma daha önceden yapılmamıştır. BAP içeriklerinin neler olduğu ve hangi konulara, nasıl, ne zaman ve hangi kalemlere bilimsel araştırma desteği verildiğini analiz eden bir çalışma literatürde mevcut değildir. Bununla beraber, araştırmaya konu olan yükseköğretim kurumlarındaki bilimsel araştırma desteklerinin içerik ve nitelik bağlamında incelenmesi ve odak konularının ortaya çıkarılması da önem arz etmektedir. Bu çalışma sonucunda araştırılan proje kapsamlarının ve içeriklerinin hangisinin ya da hangilerinin geçerli ve yararlı olduğu bulunacak, gelecekte gerçekleştirilecek bilimsel projelere ve araştırmalara öncü olunabilecek ve BAP gerçekleştirmek isteyen akademisyenlere yol gösterici olacaktır. Bu araştırma ile BAP çalışmalarına katkı sağlanması ümit edilmektedir.

Yükseköğretim kurumlarında yıllara göre araştırmaya ayrılan bütçelerin değişimi aşağıda tablo a'da gösterilmiştir (TÜBİTAK, 2017): 


\section{Tablo a.}

Yükseköğretim Kurumlarına Verilen Genel Destek Verileri

\begin{tabular}{lllll}
\hline Y1l & $\begin{array}{l}\text { Önerilen } \\
\text { Proje Sayısı }\end{array}$ & $\begin{array}{l}\text { Destek Kararı Verilen } \\
\text { Proje Sayısı }\end{array}$ & $\begin{array}{l}\text { Yürürlükteki } \\
\text { Proje Sayısi }\end{array}$ & $\begin{array}{l}\text { Yürürlükteki Projelere } \\
\text { Aktarılan Tutar } \\
\text { (2017 Deşate-Milyon) }\end{array}$ \\
\hline 2002 & 1.198 & 548 & 1.242 & 19,3 \\
\hline 2003 & 867 & 338 & 1.227 & 17,7 \\
\hline 2004 & 1.742 & 480 & 1.353 & 24,0 \\
\hline 2005 & 4.203 & 1.480 & 2.359 & 158,4 \\
\hline 2006 & 4.163 & 1.366 & 3.160 & 413,5 \\
\hline 2007 & 5.005 & 1.304 & 3.472 & 604,6 \\
\hline 2008 & 4.944 & 1.188 & 3.295 & 490,2 \\
\hline 2009 & 4.910 & 911 & 2.834 & 610,5 \\
\hline 2010 & 5.154 & 1.239 & 2.652 & 589,0 \\
\hline 2011 & 5.060 & 1.234 & 2.695 & 437,1 \\
\hline 2012 & 6.182 & 1.131 & 2.725 & 399,9 \\
\hline 2013 & 7.856 & 1.701 & 3.109 & 494,0 \\
\hline 2014 & 9.623 & 2.254 & 4.212 & 629,5 \\
\hline 2015 & 12.116 & 2.153 & 5.122 & 749,3 \\
\hline 2016 & 7.848 & 894 & 4.198 & 696,8 \\
\hline & & & &
\end{tabular}

TÜBİTAK internet sitesinde 2000-2016 yllarını kapsayan tarihler arasında yükseköğretim kurumlarına verilen proje desteklerini gösteren tablo a incelendiğinde; 2005 yllından itibaren gerek proje sayllarının, gerek bütçe büyüklüklerinin arttığı görülmekle birlikte, 2008 yılından 2010 yllına kadar bir düşüş meydana gelmiştir. 2010 yılı ve sonrasında artış devam etmektedir. 2002 yılında 548 proje önerisi sunulur iken, bu rakam 2014 yılında 9.623'e yükselmiştir. En çok proje önerisinin sunulduğu y1l 12.116 ile 2015 olmuştur. Toplam proje bütçeleri incelendiğinde ise en yüksek bütçenin yine 2015 yılı itibari ile 5.122 proje ile 749,3 milyon TL olduğu görülmektedir. En düşük bütçenin verildiği yıl 17,7 milyon TL ile 1227 bütçeli 2003 yılıdır. 2015 yılında TÜBİTAK'ın gerek proje öneri sayısında gerekse proje bütçelerinde en yüksek düzeyde destek verdiği dönem olarak görülmektedir. $\mathrm{Bu}$ tarihte 5.122 proje desteklenmeye devam ederken, bu projelere 749,3 milyon TL gibi bir bütçe verilmiştir. 2016 yllında ise proje başvuruları ve destek verilen proje sayılarında bir düşüş meydana gelmiş, önerilen proje sayısı 78.484 'e, proje bütçeleri ise 696,8 milyon TL’ye düşmüştür. 


\section{Araştırmanın Amacı}

$\mathrm{Bu}$ araştırmanın amacı, Türkiye'deki üniversitelerin akademisyenlere BAP vasıtasıyla sağladığı bilimsel araştırma desteklerini belirli kriterler açısından inceleyip mevcut durumu ortaya koymak ve gelecekte yapılması muhtemel projelere ve alan çalışmalarına yol göstermektir. Araştırmanın belirtilen amacı doğrultusunda aşağıda bulunan araştırma sorularına yanıtlar aranmaktadır:

1. BAP koordinatörlükleri kaç yllında kurulmuştur?

2. BAP koordinatörlüklerinin web siteleri kullanılır durumda mıdır?

3. BAP birimlerinin faaliyet raporları ulaşılabilir durumda mıdır?

4. BAP birimlerinin faaliyet raporları hangi tarihleri kapsamaktadır?

5. Desteklenen BAP projeleri kaç tanedir?

6. Desteklenen BAP projesi türleri nelerdir?

7. Yükseköğretim kurumlarında BAP için online başvuru imkânı mevcut mu?

8. BAP projeleri başvuru dönemleri nasıldır?

9. BAP projeleri bütçe harcama kalemleri nelerdir?

10. BAP projeleri süreleri ne kadardır?

11. BAP için akademisyenler kaç projeye başvurabilir?

12. En fazla BAP desteği alan üniversiteler hangileridir?

13. Destek kararı verilen BAP projelerinin yıllara göre dağılımı nasıldır?

Araştırmanın sonuçları kullanılarak Türkiye'de üniversitelerde öne çıkan bilimsel araştırma proje konuları ve içerikleri görülebilecek, bilimsel araştırma proje komisyonları incelenebilecek, BAP kapsamındaki aktif üniversite sayıları tespit edilebilecektir. Aynı zamanda proje başvuru aralıkları ve süreleri tespit edilebilecek, bütçe harcama kalemleri ortaya çıkarılacak, faaliyet raporları ulaşılabilirliği ve akademisyenlerin kaç projeye başvurabileceği incelenen üniversiteler bağlamında tespit edilebilecektir. Böylece gelecekte yapılması planlanan bilimsel araştırma konularının seçiminde araştırmacılara ışık tutabilecek ve yeni bir bakış açısı getirebilecektir. Bilimsel araştırma projeleri ile ilgilenen akademisyenler için bu araştırma, nicelik ve nitelik açısından da açıklayıcı olacaktır. Uluslararası bağlamda bilimsel araştırma destekleri yaygın bir şekilde verilmekte ve bu desteklerin analizleri belli aralıklarla yapılmaktadır. Buna benzer araştırmaların ve analizlerin BAP kapsamında Türkiye'de de düzenli olarak yapılması önemlidir. Ayrıca bu araştırmanın BAP gerçekleştirmek isteyen akademisyenler için alana katkı sağlayabileceği düşünülmüştür. Öte yandan yükseköğretim kurumlarındaki bilimsel araştırma projelerinin içerik olarak irdelenmesi ve bu vesile ile bilim üzerine yaptığı katkıların be- 
lirlenmesinin, bulunan duruma ışık tutmanın yanında, gelecek dönemlerde takip edilecek araştırma politikalarını da yönlendireceği düşünülmektedir. Sonuç olarak, gelecekte yapılacak bilimsel araştırmaların daha özgün ve daha yenilikçi olmaları konusunda katkı sağlayabilecek bulguların bilimsel araştırma verileri kapsamında önemli bir işlevi olacağı düşünülmektedir.

\section{Yöntem}

$\mathrm{Bu}$ araştırma betimsel tarama modelinde kurgulanmıştır. Tarama modelleri, geçmişte ya da halen var olan bir durumu var olduğu şekliyle betimlemeyi amaçlayan araştırma yaklaşımıdır. Onları herhangi bir şekilde değiştirme, etkileme çabası gösterilmez (Karasar, 2010, s. 77). Betimsel araştırmalar; nedir sorusuna cevap vererek olayları, nesneleri, kurumları, grupları ve çeşitli durumları açıklamaya çalışmaktadır. Bu sayede onları olduğu gibi anlayabilme, tasnif edebilme imkânı sağlanır (Kaptan, 1998). Bilimin açıklama işlevinin ön planda olduğu betimsel tarama modelinde gözlem, kaydetme, olaylar arasındaki ilişkileri tespit etme ve kontrol edilen değişmez ilkeler üzerinde genellemelere varma nitelikleri söz konusudur (Yıldırım \& Şimşek, 2006).

\section{Evren ve Örneklem}

Çalışmada evreni olarak kurumsallaşma bakımından belli bir aşamaya gelmiş üniversiteler belirlenmiştir. Bu doğrultuda 2000 yllı baz alınarak 2000 yılı ve öncesinde kurulan (1933-1999) 73 üniversite çalışma evrenini oluşturmuştur. Çalışma kapsamında 2000 yılı ve öncesinde kurulan üniversitelerin tümüne ulaşılmıştır. Araştırmanın örneklemine ise BAP verilerine ulaşılabilen 30 üniversite dâhil edilmiştir.

\section{Verilerin Analizi}

Bu araştırmada, yükseköğrenim kurumlarındaki bilimsel araştırma destekleri; birimlerin kuruluş yılları, komisyon üye sayıları, web sitesi erişimi, faaliyet raporlar1 ulaşılabilirliği, bilimsel araştırma destek türleri, başvuru türleri, başvuru tarih aralıkları, bütçe kalemleri, BAP süreleri ve akademisyenlerin kaç projeye başvurabileceği başlıkları inceleme kapsamına alınmıştır. Bu inceleme için içerik analiz tekniği kullanılmaktadır. İçerik analiz tekniği, sosyal bilimler çalışmalarında bir hayli yoğun şekilde kullanılan bir analiz aracıdır. Sosyal iletişimin kanıtları olarak adlandırılan mesajlar, yazılı dokümanlar ya da sesli iletişimin kâğıda aktarılmış çö- 
zümlemeleridir. İçerik analizi uzmanı, dokümanların üstünde hassas ekipmanlar ile çalışan bir dedektife benzetilmektedir (Bilgin, 2006). Krippendorf (2004), kitabında içerik analizini verilerden geçerli olan sonuçlar ve tekrar eden açıklamalar yapmak adına kullanılan araştırma yönteminin adı olarak ifade eder.

İçerik analizinde birinci aşamada, örneklem grubumuzda bulunan 2000 yılı ve öncesinde kurulan 30 üniversitenin BAP birimlerinin verileri bilgisayar dosyalarına aktarılmıştır. Söz konusu yükseköğretim kurumlarının BAP birimlerinin analizinde içerik analizi kullanılmıştır. İçerik analizinde kodlama ve kategoriler çok önemlidir. Oluşturulan kategoriler çok açık olmalı ve araştırmanın verileri bir başka araştırmacı tarafından analiz edildiğinde aynı sonuçlara ulaşılabilmelidir (Fraenkel \& Wallen, 2005). İçerik analizi elde edilen verilerin kavramsallaştırılması, anlamlı şekilde düzenlenmesi ve temaların oluşturulması sürecini kapsamaktadır (Yıldırım \& Şimşek, 2013).

Çalışmada elde edilen bulguların geçerliliğinin sağlanması için içerik analizi sınıflamalarında kullanılan ve bir yükseköğretim kurumunun BAP biriminin temel özellikleri olan unsurların tamamı inceleme kapsamına alınmıştır. Verilerin güvenirliğinin sağlanması için ise verilerin konu alanlarına göre kodlanması ve yorumlanmasında araştırmacılar tarafından tartışmalar yürütülmüş ve alan uzmanlarının görüşleri alınmıştır.

Araştırmada toplanan veriler, SPSS paket programı vasıtası ile yüzde ve frekansları hesaplanarak analiz edilmiştir. Frekans analiz yöntemi, en sade tanımıyla kayıtların sayısal olarak görülme olasılığının ortaya çıkarılmasıdır. Frekans analizlerinin sonuçları bağlamında kodlanmış birim olasılığına bakılarak sınıflama yapılmakta ve ögelerin önem sırası verilmektedir (Bilgin, 2006).

\section{Bulgular}

Bu bölümde, içerik analizi yöntemi ile Türkiye'de 2000 yılı ve öncesinde kurulan (1933-1999) 30 yükseköğretim kurumunun BAP komisyonlarının web sitelerinin, projelerinin incelenmesi sonunda elde edilen bulgulara yer verilmiştir.

\section{BAP Koordinatörlüklerinin Kuruluş Yılları}

Yükseköğretim kurumlarının BAP komisyonlarının kronolojik olarak kuruluş yıllar1 ve sayısal ortalaması tablo 1'de gösterilmiştir. 
Tablo 1.

BAP Koordinatörlüklerinin Kuruluş Yılları

\begin{tabular}{lll}
\hline Yillar & $\mathbf{f}$ & $\mathbf{\%}$ \\
\hline 1984 & 1 & 3,3 \\
\hline 1995 & 1 & 3,3 \\
\hline 1999 & 2 & 6,6 \\
\hline 2002 & 14 & 47 \\
\hline 2009 & 1 & 3,3 \\
\hline 2014 & 2 & 6,6 \\
\hline Belirtilmemiş & 9 & 29,9 \\
\hline TOPLAM & $\mathbf{3 0}$ & $\mathbf{1 0 0}$ \\
\hline
\end{tabular}

Tablo 1'de koordinatörlük kuruluş yıllarına bakıldığında 14 üniversitenin \%47 oranla 2002 yılında oluşturduğu görülmektedir. 2547 Sayılı Yükseköğretim Kanununa göre; üniversitelerde alınan kararlar ile 2001 mali yılı sonuna kadar araştırma fonu olarak hizmet veren birimler, araştırma fonlarının kapatılmasıyla 2002 yllinda yeniden yapilanarak "BAP Koordinasyon Birimi" olarak hizmet vermeye başlamıştır (YÖK, 2016). Bu yüzden yükseköğretim kurumlarında 2002 yılında ve sonrasında kurulan BAP koordinatörlüklerinin sayıları bir hayli fazladır. \%29 oranlı 9 üniversitenin BAP koordinatörlüklerinin kuruluş yılları belirtilmemiştir. Bununla beraber \%6,6 oranla 4 üniversite, 2014 ve 1999 yllarında koordinatörlüklerini kurmuştur. \%3,3 oranla 2 üniversite de 1995 ve 1984 yllında hizmete girmiştir. Kuruluş yılları bağlamında BAP koordinatörlüklerine bakıldığında ihtiyaç dâhilinde değil; kararlar neticesinde kurulduklarını söyleyebiliriz. Koordinasyon Birimleri, BAP Komisyonu'na bağlı olarak sekretarya hizmetlerinin ve üniversite bünyesindeki projelerin (BAP, DPT ve TÜBİTAK) idari ve mali anlamda tüm işlemlerinin yerine getirilmesi amacıyla kurulmuştur (Boz, 2011). Bu bağlamda kuruluş yılları ile yükseköğretim kurumlarının bilimsel araştırma desteklerine duydukları ihtiyaç paralellik göstermektedir.

\section{BAP Koordinatörlüklerinin Web Sitelerini Kullanım Durumu}

BAP koordinatörlüklerinin web sitelerini kullanım durumu (güncellik, başvuru sistemleri, duyurular, birimler, anlaşılabilirlik) tablo 2'de gösterilmiştir. 
Tablo 2.

BAP Web Sitelerini Kullanım Durumu

\begin{tabular}{lcc}
\hline Kullanım Durumu & $\mathbf{f}$ & $\mathbf{\%}$ \\
\hline Aktif & 18 & 60 \\
\hline Kismen Aktif & 10 & 33.3 \\
\hline Pasif & 2 & 6.7 \\
\hline TOPLAM & $\mathbf{3 0}$ & $\mathbf{1 0 0}$ \\
\hline
\end{tabular}

Bilgisayar ve internet imkânlarının artması ile kurumlar için web adreslerinin önemi de artmıştır. Web sayfaları kurumların dünyaya ve insanlara açılan kapıları olmakta ve bu sayede kurumlar ilgili şahıslara çok kolay ulaşmaktadır (Ateş \& Karacan, 2009). Tablo 2'de gösterildiği üzere, 30 üniversitenin BAP koordinatörlüklerinin web sitelerinin kullanım durumu incelendiğinde \%60 oranla 18 üniversitenin BAP birimlerinin internet sitelerini aktif bir şekilde kullandığ1 görülmektedir. Aktif şekilde kullanılan web adresleri sayesinde, bilimsel araştırma yapmak isteyen akademisyenler, elde etmek istedikleri verilere ve kaynaklara (faaliyet raporları, başvuru formları, güncel veriler, birim başkanları, telefon numaraları, başvuru tarihleri, zaman aralıkları, başvuru tipleri, proje tipleri vb.) kolayca ulaşabilmektedirler. \%33,3 oranla 10 üniversite ise web sitelerini kısmen aktif kullanmaktadırlar. Kısmen aktiflik statüsüne sahip BAP koordinatörlüklerinin internet sitelerini zorunluluktan dolayı oluşturdukları görülmektedir. Web sitelerinde genellikle, "bakım aşamasında, ulaşılamıyor ve sınırlı sayıda veri, vb." internet terimleri ile karşılaşılmaktadır. Bununla beraber, web adresleri kolay kullanılır, yol gösterici ve yardım edebilecek kapasitede değildir. \%6,7 oranla 2 üniversitenin BAP koordinatörlüklerinin web sitesi ise aktif değildir. BAP web adreslerinde projelerle ilgili idari işlemler arasında, proje başvurularının alınması, kabul edilen projelerin duyurulması, projelerin ara ve kesin raporlarının takibi ve sonuçlandırılması bulunmaktadır (Boz, 2011). BAP projesi gerçekleştirmek ve uzaktan erişim ile bilgi almak isteyen akademisyenler için büyük bir sinırlllıktır. Koordinatörlüğün web adresinin aktif olmaması, araştırmacıların birimle sürekli telefonla veya yüz yüze irtibat kurma zorunluluğunu ortaya çıkaracak; bilim insanlarının zamandan kaybetmelerine sebep olunacaktır. 


\section{BAP Koordinatörlüklerinin Faaliyet Raporlarının Ulaşılabilirliği ve Tarihleri}

Yükseköğretim kurumlarının BAP birimlerinin faaliyet raporlarının ulaşılabilirlik durumları ve tarih aralıkları tablo 3 ve 4'te gösterilmiştir.

\section{Tablo 3.}

BAP Koordinatörlüklerinin Faaliyet Raporlarının Ulaşılabilirliği

\begin{tabular}{lll}
\hline Faaliyet Raporları & $\mathbf{f}$ & $\mathbf{\%}$ \\
\hline Ulaşılabilir & 20 & 66,7 \\
\hline Ulaşılamaz & 10 & 33,3 \\
\hline TOPLAM & $\mathbf{3 0}$ & $\mathbf{1 0 0}$ \\
\hline
\end{tabular}

Eğitim kurumlarının ve okulların hesap verebilirlik sistemlerine bakıldığında, kaliteli ve güçlü bir kurum yapısına ve okul kültürünün gelişmesine destek vermektedir. Eğitim kurumlarından hizmet alan ve faydalanan tüm bireyler, hesap verilebilirlik aracılığı ile elde ettikleri tüm imkânları değerlendirebilir ve eğitim kurumlarının daha aktif hale gelmesini sağlayabilirler (Göker \& Gündüz, 2017). Tablo 3'te görüldüğü üzere, 30 üniversitenin BAP koordinatörlüklerinin faaliyet raporlarının ulaşılabilirliği incelenmiş, \%66,7 oranla 20 üniversitenin BAP faaliyet raporlarının ulaşılabilir kategoride olduğu, \%33,3 oranla 10 üniversitenin ise faaliyet raporlar1nın ise ulaşılamaz kategoride olduğu görülmektedir. Yükseköğretim kurumlarının BAP koordinatörlüklerindeki bu durum, eğitim yönetimi ve denetiminin de konu alanı içerisinde yer alan "şeffaflık ve açıklık", aynı zamanda "hesap verilebilirlik" ilkeleri ile bağdaşmamaktadır. Yapılan bilimsel faaliyetlerin raporlarının kamuoyu ile paylaşılmaması büyük bir sınırlılıktır. Bununla beraber, faaliyet raporlarını paylaşan üniversitelerin sayılarının çoğunlukta olması sevindiricidir. 
Tablo 4.

BAP Faaliyet Raporları Yayınlamaya Başlama Tarihleri

\begin{tabular}{lll}
\hline Tarih Aralıklari & $\mathbf{f}$ & $\mathbf{\%}$ \\
\hline 1998 & 1 & 5 \\
\hline 2000 & 3 & 15 \\
\hline 2002 & 1 & 5 \\
\hline 2003 & 1 & 5 \\
\hline 2005 & 1 & 5 \\
\hline 2007 & 1 & 5 \\
\hline 2008 & 2 & 10 \\
\hline 2009 & 3 & 15 \\
\hline 2010 & 2 & 10 \\
\hline 2011 & 1 & 5 \\
\hline 2012 & 1 & 5 \\
\hline 2013 & 2 & 10 \\
\hline 2014 & 1 & 5 \\
\hline TOPLAM & $\mathbf{2 0}$ & $\mathbf{1 0 0}$ \\
\hline
\end{tabular}

Tablo 4'te, 30 üniversitenin BAP koordinatörlüklerinin faaliyet raporlarını kamuoyuna sundukları tarihler verilmiştir. Üniversitelerin BAP koordinatörlüklerinin kuruluş yılları ile paralellik gösteren faaliyet raporları yayınlama tarihleri ayı zamanda web adreslerinin kullanımı ile de alakalıdır. Web sitelerini kuran BAP birimleri, faaliyet raporlarını da paylaşmaya başlamışlardır. Uzaktan erişim ile verilere erişmek isteyen araştırmacılar, web sitesi kullanışlı ve ulaşılabilir BAP birimlerinden verileri daha kolay elde edebilmektedirler.

Eğitim ve yönetim yapılarının gelişmiş olarak en önemli özelliklerinden biri de hesap verilebilirliktir. Hesap verebilirlik, bir kuruluştaki çalışanların, yetkili ve sorumlu oldukları şahıslara cevap verme ve eleştirilere açık olma, aynı zamanda durumlara uygun davranışlarda bulunma ve bir başarısızlık, yetersizlik veyahut hilekârlık durumlarında sorumlu olan kişinin kendisi olduğunu bilmektir (UNDP, 1998, s. 1). Yayın tarihi başlangıcının geniş bir yelpazeye sahip olması, BAP koordinatörlüklerinin işini düzenli bir şekilde yaptığının ve aynı zamanda şeffaf bir şekilde kamuoyu ile çalışmalarını paylaştığının bir göstergesidir. 


\section{Desteklenen BAP Projesi Türleri Sayıları}

Yükseköğretim kurumları vasıtasıyla desteklenen BAP proje türleri sayıları tablo 5’te gösterilmiştir.

\section{Tablo 5.}

Desteklenen BAP Proje Türleri Sayıları

\begin{tabular}{lll}
\hline Sayllar & $\mathbf{f}$ & $\mathbf{\%}$ \\
\hline 2 & 2 & 6.7 \\
\hline 5 & 3 & 10 \\
\hline 7 & 2 & 6.7 \\
\hline 8 & 4 & 13.3 \\
\hline 9 & 5 & 16.7 \\
\hline 10 & 2 & 6.7 \\
\hline 11 & 1 & 3.3 \\
\hline 12 & 5 & 16.7 \\
\hline 13 & 2 & 6.7 \\
\hline 15 & 2 & 6.7 \\
\hline 16 & 1 & 3.3 \\
\hline 19 & 1 & 3.3 \\
\hline TOPLAM & $\mathbf{3 0}$ & $\mathbf{1 0 0}$ \\
\hline
\end{tabular}

Türkiye'de hem eğitim alanında yapılan araştırmalar ve harcamalar hem de okullaşma oranı, AB ülkelerine göre çok düşük seviyede kalmaktadır. Aynı zamanda yükseköğrenimden tutun da ilköğretime kadar her eğitim seviyesinde sınıf başına düşen öğrenci sayısı fazladır. Nitelikli ve kaliteli eğitim için, eğitim ve araştırma olanaklarına daha çok kaynak ayrılmalı, bu kaynaklar ise ihtiyaç duyulan gereksinim alanına ve düzeyine göre pay edilmeli ve denetimi sağlanmalıdır (Çalışkan, 2006). Yükseköğretim kurumlarımızda bilimsel araştırma desteklerinde durum aynıdır. Bilimsel araştırmalara ayrılacak destek miktarı, alana ve ihtiyaca göre eşit ve ihtiyaç dâhilinde pay edilmelidir.

Tablo 5 'te 30 üniversitenin BAP koordinatörlüklerinin destekledikleri proje başlığı sayılarına baktığımızda \%16,7 oranla 9 adet proje başlı̆̆ sunan 5 yükseköğretim kurumu, yine \%16,7 oranla 12 adet proje başlı̆̆ sunan 5 yükseköğretim kurumu 
göze çarpmaktadır. Bu oranları \%13,3 oranla 8 proje başlığı sunan 4 üniversite ve \%10 oranla 5 proje başlığı sunan 3 yükseköğretim kurumu izlemektedir. Aynı şekilde \%6,7 oranla $15,13,10,7$ ve 2 proje başlığı sayısı sunan yükseköğretim kurumu sayısı 2'şer iken; \%3,3 oranla 19,16 ve 11 proje başlığı sunan yükseköğretim kurumu sayısı yalnızca 1'dir.

Yükseköğretim kurumlarındaki proje türlerinin fazlalığ1, öğretim üyelerinin proje başvurularının çeşitliliğine, yükseköğretim kurumlarındaki bölümlerin ve içeriklerinin çeşitliliğine, lisans ve lisansüstü öğrencilerinin ilgi alanlarının ve yeteneklerinin çeşitliliğine, üniversitenin maddi imkânlarına ve nitelikli BAP çalışanı sayısına da bağlıdır. Bu yüzden yükseköğretim kurumları genelinde kendi komisyonlarında ve BAP toplantılarında aldıkları kararlar ile yıllara göre proje başlıkları çeşitlenmekte veyahut düzenlenmektedir. BAP çeşitlerinin bir yükseköğretim kurumunda fazla olması, bilimsel araştırma gerçekleştirecek akademisyenlerin de ilgi, yetenek ve kabiliyetleri doğrultusunda daha nitelikli projeler üretmesine ve bilime daha çok katkı sağlayacak sonuçlar ortaya çıkarmasına sebebiyet verecektir.

\section{Desteklenen BAP Projeleri Türlerinin Dağılımı}

Yükseköğretim kurumlarının çatısı altında gerçekleştirilen BAP projelerinin türlerinin dağılımı ve yükseköğretim kurumları tarafından maddi destek verilme oranı tablo 6’da gösterilmiştir.

\section{Tablo 6.}

Desteklenen BAP Projeleri Türlerinin Dağılımı ve Desteklenme Oranı

\begin{tabular}{lll}
\hline Proje Türleri & \multicolumn{2}{l}{$\begin{array}{l}\text { Destek Veren } \\
\text { Üniversite Sayısı ve Oranı }\end{array}$} \\
\hline Lisanüstü Tez Projeleri & $\mathbf{f}$ & $\mathbf{\%}$ \\
\hline Bilimsel AR-GE İçin Altyapı Destek Projeleri & 30 & 100 \\
\hline Hızlı Destek Araştırma Projeleri & 22 & 73,3 \\
\hline Bilimsel Etkinliklere Katılım ve Düzenleme Desteği & 18 & 63.3 \\
\hline Fikir Mülkiyet Hakları ve Patent Desteği & 19 & 60 \\
\hline Uluslararası Araştırma Projeleri & 18 & 56,7 \\
\hline Güdümlü Araştırma Projeleri & 17 & 46,7 \\
\hline Sanayi İş Birliği Projeleri & 14 & 43,3 \\
\hline
\end{tabular}




\begin{tabular}{|c|c|c|}
\hline Normal Araştırma Projeleri & 12 & 40 \\
\hline Çok Disiplinli Öncelikli Alan Projeleri & 12 & 40 \\
\hline Lisans Öğrencisi Araştırma Projeleri & 10 & 33,3 \\
\hline Ulusal Araştırma Projeleri & 10 & 33,3 \\
\hline Araştırma Başlangıç Projeleri & 9 & 30 \\
\hline Dış Kaynaklı Projeler İçin Eş Finans Desteği & 9 & 30 \\
\hline Bağımsız Projeler & 9 & 30 \\
\hline Katılımlı Araştırma Projeleri & 8 & 26,7 \\
\hline Araştırma ve İş birliği Geliştirme Projeleri & 7 & 23,3 \\
\hline Bilimsel Yayın Teşviki Destekleri & 5 & 16,7 \\
\hline Tipta Uzmanlık Projeleri & 5 & 16,7 \\
\hline Diş Hekimliğinde Uzmanlık Projeleri & 5 & 16,7 \\
\hline Eğitim ve Teknoloji Geliştirme Desteği & 5 & 16,7 \\
\hline Genç Bilim İnsanı Destekleme Projeleri & 4 & 13,3 \\
\hline AR-GE Laboratuar Desteği Projeleri & 4 & 13,3 \\
\hline Teşvik Projeleri & 4 & 13,3 \\
\hline Kapsamlı Araştırma Projeleri & 4 & 13,3 \\
\hline Yayın Sürekliliği Teşviki Projeleri & 4 & 13,3 \\
\hline Kurum Dışı Ortak Katılımlı Projeler & 4 & 13,3 \\
\hline Tamamlayıcı Destek Projeleri & 4 & 13,3 \\
\hline Temel Araştırma Projeleri & 3 & 10 \\
\hline Sektörel Destekli BAP Projeleri & 3 & 10 \\
\hline Konuk Bilim ve Sanat İnsanı Desteği & 3 & 10 \\
\hline AB Çerçeve Program Projeleri & 2 & 6,7 \\
\hline Bilimsel ve Teknolojik Araştırma Desteği & 2 & 6,7 \\
\hline Bilimsel Entegrasyon Desteği & 1 & 3,3 \\
\hline Stratejik Araştırma Desteği & 1 & 3,3 \\
\hline Performans Projeleri & 1 & 3,3 \\
\hline Tasarım Projeleri & 1 & 3,3 \\
\hline
\end{tabular}




\begin{tabular}{lll}
\hline Kariyer Programlama Projeleri & 1 & 3,3 \\
\hline Otomasyon Yazılım Desteği Projeleri & 1 & 3,3 \\
\hline Akreditasyon Başvuru Desteği Projeleri & 1 & 3,3 \\
\hline Kritik Çalışma Desteği Projeleri & 1 & 3,3 \\
\hline Analiz Desteği Projeleri & 1 & 3,3 \\
\hline Eğitim Öğretim Teşviki Desteği Projeleri & 1 & 3,3 \\
\hline Toplumsal Sorumluluk Projeleri & 1 & 3,3 \\
\hline İleri Araştırma Projeleri & 1 & 3,3 \\
\hline Bölgesel Projeler & 1 & 3,3 \\
\hline TOPLAM DESTEKLENEN PROJE TÜRÜ SAYISI & & $\mathbf{4 6}$ \\
\hline
\end{tabular}

Tablo 6'da gösterildiği üzere, 30 yükseköğretim kurumunun desteklediği bilimsel araştırma proje türlerine ve desteklenme oranına bakıldığında araştırma bulgularında 46 adet proje türüne rastlanılmaktadır (Proje türleri, BAP komisyon toplantıları ve faaliyetleri neticesinde her sene yenilenebilir ve değişikliğe uğrayabilir). Bu proje adlarından \%100 oranla "Lisansüstü tez projeleri" tüm üniversiteler tarafından desteklenmektedir. Bu destek yüzdesi göstermektedir ki, yüksek lisans ve doktora seviyesindeki araştırmacıların yaptıkları araştırmalar, yükseköğretim kurumları tarafından önemsenmektedir. Aynı zamanda araştırmacıların bilime sağladığı katkı düşünüldügünde bu eğitim ve tez dönemlerinde bilimsel destek almaları, daha nitelikli lisansüstü araştırmalar ortaya koymalarına yardımcı olacaktır.

"Bilimsel AR-GE için altyapı destek projeleri" \%73,3 oranla 22/30 üniversite tarafından en çok destek alan 2. proje başlığıdır. Araştırma ve Geliştirme faaliyetleri, kalkınma ülkeleri açısından bakıldığında büyük önem arz etmekte ve hızla büyüyen ekonominin bir temeli olarak nitelendirilmektedir. Bu sebep ile AR-GE faaliyetleri ve altyapı destekleri bilimin daha nitelikli ve kaliteli yapılması için önemlidir. Araştırmacıların bu proje başlığı ile destek alacakları vakitte; bilime, sanata ve projeyi gerçekleştirecekleri alana somut katkılar ve temeller atmaları istenmektedir.

"Hızlı destek araştırma projeleri” ise \%63,3 oranla 3. sırada, 19/30 yükseköğretim kurumu tarafından destek verilen diğer bilimsel araştırma desteği başlı̆̆ olarak karşımıza çıkmaktadır. Bilimsel araştırma ve proje faaliyeti gerçekleştirecek akademisyenler için, hızlı bir şekilde kaynak, materyal, yolluk ve teçhizat vb. alımı yapılmasına yardımcı olan proje tipidir. Bu proje başlığı ile bilimsel araştırmacılar, akademik nitelikli bir sonuca ulaşmak için araç olarak kullanacakları materyallerin 
temini, sonuçların elde edilmesi için analizlerin yaptırılması ve benzer araştırmaların takibi için seyahat ödenekleri gibi kalemleri hızlı bir şekilde temin ve tedarik edebilmektedir.

"Bilimsel Etkinliklere Katılım ve Düzenleme Desteği” akademisyenlerin yoğun olarak tercih ettiği ve araştırma kapsamında \%60 oranla 4 . sırada yer alan ve 18/30 yükseköğretim kurumu tarafından desteklenen bir diğer proje adıdır. Bu proje başlığı ile bilimsel bir araştırma gerçekleştirmiş olan akademisyenler, kendi alanlarını kapsayan bir kongre, panel, sempozyum, eğitim ve sunum faaliyeti için gerekli olan tüm gereksinimleri bu gruptan karşılamaktadırlar.

"Fikir Mülkiyet Hakları ve Patent Desteği” bilimsel araştırmacıların yoğun olarak başvurduğu proje başlıkları arasındadır. Araştırma kapsamında, \%60 oranla 5. sırada yer alan proje başlğı, 18/30 yükseköğretim kurumu tarafından desteklenmektedir. Bu proje adı başlığı ile bilimsel araştırmacılar, ortaya çıkardıkları fikir, mal hakkı, ürün patentini almak için yükseköğretim kurumlarından destek isterler. BAP komisyonları ve hakemlerinin incelemeleri neticesinde karara bağlanan proje sonuçları ile istedikleri destek miktarları kendilerine aktarılır.

Araştırma bağlamında "Uluslararası araştırma projeleri” \%56,7 oranla 17; "Güdümlü araştırma projeleri” \%46,7 oranla 14; "Sanayi iş birliği projeleri” \%43,3 oranla 14; "Normal araştırma projeleri ve Ulusal araştırma projeleri" \%46,6 oranla 14; "Lisans öğrencisi araştırma projeleri ve Ulusal araştırma projeleri" \%33,3 oranla 10; "Araştırma başlangıç projeleri, Dış kaynaklı projeler için eş finans desteği ve Bağımsız projeler" \%30 oranla 9; "Katılımlı araştırma projeleri" \%26,7 oranla 8; "Araştırma ve iş birliği geliştirme projeleri" \%23,3 oranla 7; "Bilim yayın teşviki destekleri, Tıpta uzmanlık projeleri, diş hekimliğinde uzmanlık projeleri, Eğitim ve teknoloji geliştirme projeleri” 16,7 oranla 5; “Genç bilim insanı destekleme projeleri, AR-GE laboratuvar desteği projeleri, teşvik projeleri, Kapsamlı araştırma projeleri, Kapsamlı araştırma projeleri, Yayın sürekliliği projeleri, Kurum dışı ortak katılımlı projeler ve Tamamlayıcı destek projeleri" \%13,3 oranla 4; "Temel araştırma projeleri, Sektörel destekli araştırma projeleri, Konuk bilim ve sanat insanı desteği”" \%10 oranla 3; "AB çerçeve program projeleri, Bilimsel ve teknolojik araştırma desteği” \%6,7 oranla 2 yükseköğretim kurumu tarafından destek almaktadır.

\%1 oranla sadece 1 yükseköğretim kurumu tarafından desteklenen proje adlarını "Bilimsel entegrasyon desteği, Stratejik araştırma desteği, Performans projeleri, Tasarım projeleri, Kariyer programlama projeleri, Otomasyon yazılım desteği, Akreditasyon başvuru desteği, Kritik çalışma desteği, Analiz desteği projeleri, Eğitim öğretim teşviki desteği, Toplumsal sorumluluk projeleri, İleri araştırma projeleri ve Bölgesel projeler" oluşturmaktadır. 
Bu dağılımdan elde edilecek sonuç ise; yükseköğretim kurumları bağlamında, farklı proje başlıklarına yüksek oranda çeşitlilik ile destek verilmektedir. Bilimsel olarak sadece belirli alana sınırlı kalınmamakta, enstitü, fakülte ve yüksekokullar için her akademik alana ve bölüme uygun destek fonu bulunmaktadır. Genel bağlamda baktığımızda ise, en yaygın olarak Lisansüstü tez projeleri, AR-GE ve altyapı destek projeleri ve Hızlı destek araştırma projeleri, BAP projelerinin büyük bir yüzdesini oluşturmaktadır.

\section{Yükseköğretim Kurumlarında BAP Projeleri İçin Online Başvuru İmkânı}

Yükseköğretim kurumlarında BAP projeleri için çevrimiçi başvuru imkânı tablo 7’de gösterilmiştir.

\section{Tablo 7.}

Yükseköğretim Kurumlarında BAP Projeleri için Online Başvuru İmkânı

\begin{tabular}{lll}
\hline Online Başvuru İmkânı & f & $\mathbf{\%}$ \\
\hline Var & 27 & 90 \\
\hline Yok & 3 & 10 \\
\hline TOPLAM & $\mathbf{3 0}$ & $\mathbf{1 0 0}$ \\
\hline
\end{tabular}

Geçmişten günümüze kadar gözlenen tüm eğitim teknolojilerinin odağında bilginin sahip olduğu gezinme ve paylaşma hızına erişmek vardır. Bu bağlam ile teknoloji vasıtası ile televizyon, radyo, video ve bilgisayar ürünleri eğitim sisteminin hizmetine sunulmuştur. Günümüzde, mobil teknolojiler erişilebilir hale gelmiştir. Böylece bu teknolojilerin büyük katkılar ve kolaylıklar sağlayacağı hizmet alanları açılmıştır (Bulun vd., 2004).

Tablo 7'de 2000 y1lı öncesinde kurulan 30 yükseköğretim kurumunun BAP koordinatörlüklerinin çevrimiçi başvuru imkânı sunulmuş ve \%90 olanla 27 üniversitenin çevrimiçi olarak başvuruları kabul ettiği, \%10 oranla 3 üniversitenin ise çevrimiçi kabul etmediği ve bireysel olarak başvuruların yapıldığ1 görülmüştür. Üniversitelerin teknolojiyi kullanması, bilimsel faaliyetlerinin duyurularını web siteleri üzerinden yapması ve araştırmacıları yormadan hizmetlerini gerçekleştirmeleri hem teorik açıdan hem de pratik açısından önemlidir. Başvuru yapılan projelerin çevrimiçi ortamda sisteme yüklenmesi, hakemler tarafından değerlendirilmesi ve geniş kitleler ile paylaşılması daha nitelikli ve sağlıklı olacaktır. Aynı zamanda komisyon üyelerinin de başvuru yapılan projeleri sistem üzerinden incelemesi, birimlerin dosyaları elden ulaştırmasından daha geçerli olacaktır. 


\section{BAP Projeleri Başvuru Dönemleri}

Yükseköğretim kurumlarının BAP projelerine başvuru tarihi aralıkları dağılımı tablo 8'de gösterilmiştir.

\section{Tablo 8.}

BAP Projeleri Başvuru Dönemleri

\begin{tabular}{lll}
\hline Başvuru Dönemi & \multicolumn{2}{l}{ Yüksekögretim Kurumu } \\
\hline Yllda 1 & $\mathbf{f}$ & $\mathbf{\%}$ \\
\hline Yllda 2 & 3 & 10 \\
\hline Yllda 3 & 4 & 13,3 \\
\hline Her Zaman & 1 & 3,3 \\
\hline Belirtilmemiş & 20 & 66,7 \\
\hline TOPLAM & 2 & 6,7 \\
\hline
\end{tabular}

Eğitim olanakları, AR-GE imkânları ve bu AR-GE imkânlarına ulaşılabilirlik ile ekonomik büyüme arasındaki bağ, yükseköğretimde gerçekleşen gelişmelerin topluma yansımaları ile takip edilebilmektedir. Bu açıklamaya dayalı olarak; ekonomik büyüme durumları ile eğitim imkânları arasındaki ilişki üzerine yapılan çalışmalar ve araştırmalar, bilginin toplumsal boyutta verimliliği ile büyüme oranlarına etkisini ortaya koymaktadır (Tanrıkulu, 2009). Buna göre, araştırma ve geliştirme faaliyetlerinde bulunacak araştırmacıların zaman ve mekân sınırı olmaması gerekmektedir.

Tablo 8'de, yükseköğretim kurumlarının BAP koordinatörlüklerinin proje başvuru dönemleri sergilenmiştir. \%66,7 oranla 20 yükseköğretim kurumunun yll içerisinde her zaman başvuru aldığı; \%13,3 oranla 4 yükseköğretim kurumunun yılda 2 başvuru aldığı; \%10 oranla 3 üniversitenin yılda 1 başvuru aldığı ve \%3,3 oranla 1 üniversitenin de yılda bir başvuru aldığı görülmüştür. Bununla beraber, \%6,7 oranla 2 üniversitede başvuru dönemleri belirtilmemiştir.

Web ortamlarından çevrimiçi bir şekilde yılın her dönemi proje başvurusu alan üniversitelerde akademik çalışmaların, projelerin ve bilimsel çıtıların üretim sıklığının fazla olması olağan bir durumdur. Bilim insanı, elindeki imkânları en iyi şekilde kullanan, yoktan var eden ve kısıtlı imkânlar ile kaliteli ürün ortaya koyan bireyler. Şartları iyileştirilmiş bir bilim insanının daha nitelikli, kaliteli ve sürekli ürünler ortaya koyması kaçınılmazdır. Bu sebep ile yılın her döneminde kurumunun kendisine destek olacağını bilen bir bilim insanı, daha motive ve istekli bir şekilde bilim arz edecektir. 


\section{BAP Projeleri Bütçeleri Harcama Kalemleri}

Yükseköğretim kurumlarında BAP projeleri bütçeleri harcama kalemlerinin dağılımı Tablo 9'da gösterilmiştir.

\section{Tablo 9.}

BAP Bütçeleri Harcama Kalemleri

\begin{tabular}{|c|c|c|}
\hline \multirow[t]{2}{*}{ Bütçe Harcama Kalemleri } & \multicolumn{2}{|c|}{$\begin{array}{l}\text { Destek Veren } \\
\text { Üniversite Sayısı ve Oranı }\end{array}$} \\
\hline & $\mathbf{f}$ & $\%$ \\
\hline Seyahat Giderleri & 25 & 83,3 \\
\hline Sarf ve Tüketim Malzemesi Giderleri & 22 & 73,3 \\
\hline Hizmet Alım Giderleri & 20 & 66,7 \\
\hline Bilgisayar, Yazıcı vb. Donanım ve Yazılım Giderleri & 20 & 66,7 \\
\hline Makine ve Teçhizat Giderleri & 18 & 60 \\
\hline Personel Talebi Giderleri & 15 & 50 \\
\hline Kırtasiye Alım Giderleri & 12 & 40 \\
\hline Demirbaş Alımları & 10 & 33,3 \\
\hline Veri Anket Çalışmaları & 8 & 26,7 \\
\hline Araç Kiralama Giderleri & 8 & 26,7 \\
\hline Kitap Talep Giderleri & 7 & 23,3 \\
\hline Laboratuvar Cihaz Alım Giderleri & 5 & 16,7 \\
\hline Canlı Hayvan ve Yem Alım Giderleri & 5 & 16,7 \\
\hline Laboratuar Sarf Malzemesi Giderleri & 4 & 13,3 \\
\hline Kongre Katılımları & 3 & 10 \\
\hline Temsil ve Ağırlama Giderleri & 2 & 6,7 \\
\hline Bakım ve Onarım Giderleri & 2 & 6,7 \\
\hline Mamul Mal Alımları & 1 & 3,3 \\
\hline Tercüme Giderleri & 1 & 3,3 \\
\hline Panel Düzenleme Giderleri & 1 & 3,3 \\
\hline TOPLAM BÜTÇE KALEMİ ADEDİ & 21 & \\
\hline
\end{tabular}


Yükseköğretim sistemi, geçmişten günümüze gelene kadar genel olarak bir kamu hizmeti olarak algılanmış ve giderleri Amerika Birleşik Devletleri ve birkaç farklı ülke dışında hemen hemen tümü ile kamu kaynakları kullanılarak karşılanmıştır (Yükseköğretim Kurulu, 2007).

Tablo 9'da, 2000 yılı öncesinde kurulan 30 yükseköğretim kurumunun BAP projelerinin bütçe harcama kalemleri sergilenmiş ve \%83,3 oranla 25/30 üniversite tarafından desteklenen "Seyahat giderleri" en çok destek verilen bütçe harcama kalemi olarak göze çarpmıştır. Bilim insanları, yaptıkları ya da yapacakları araştırmalar için, veri toplamak adına ve etkinliklere katılmak için seyahat etmektedirler. Bu seyahatler, eğer bilimsel bir araştırma için ya da proje kapsamında yapılıyor ise, harcama kalemleri içerisinde yer alır ve yükseköğretim kurumları tarafından desteklenir.

\%73 oranla 22/30 yükseköğretim kurumu tarafından desteklenen "Sarf tüketim malzemesi giderleri”, araştırma kapsamında en çok destek verilen ve pay harcanan ikinci bütçe kalemi olarak ortaya çıkmaktadır. Bu bütçe kalemi ile yükseköğrenim kurumu BAP yönergeleri kapsamında ihtiyaç duyulan tüm sarf malzemesi gereksinimleri karşılanabilir (deney tüpü, kalem, kâğıt, büro malzemesi, temizlik malzemesi, su vb.).

Belki de projelerde en çok talep edilen ve proje kapsamında ihtiyaç duyulan bütçe kalemlerinden biri olan "Bilgisayar, yazıc1, vb. donanım ve yazılım giderleri" kalemi ise \%66,7 oranla 20/30 üniversite tarafından desteklenmektedir. Bu kalem vasıtası ile bilim araştırmasında kullanmak üzere bilgisayar veri donanımı ve yazılımlarını yükseköğretim kurumları BAP yönergeleri uygunluğu neticesinde temin edebilmektedirler.

"Hizmet alımı giderleri", \%66,7 oranla 20/30 üniversite tarafından karşılanan ve araştırma neticesinde 4. sırada olan bütçe kalemidir. Hizmet alımları, özellikle kurumlarda son zamanlarda yaygınlaşan bir istihdam kaynağı olarak karşımıza çıkmaktadır. Eğer bilimsel araştırma kapsamında nitelikli insan gücüne, çalışacak personele ya da işçiye ihtiyacınız olacak ise yükseköğretim kurumları bu kalem vasitası ile size destek sağlamaktadır.

\%60 oranla "Makine teçhizat giderleri" ise tabloda gösterildiği üzere, 18/30 üniversite tarafından desteklenmekte ve 5 . en fazla destek verilen bütçe kalemi olarak BAP yönergelerinde yer almaktadır. Bu kalem ile ihtiyaç duyulan tüm makine, elektronik eşya, materyal ve geniş tabanlı gereksinimlerinizi yükseköğretim kurumu karşılamaktadır.

Araştırma bağlamında, "Personel talebi giderleri" \%50 oranla 15/30 üniversiteden; "Kırtasiye alım giderleri” \%40 oranla 12/30 üniversiteden; "Demirbaş alım- 
ları" \%33,3 oranla 10/30 üniversiteden; "Veri anket çalışmaları ve Araç kiralama giderleri” \%26,7 oranla 8/30 üniversiteden; “Kitap talep giderleri” \%23,3 oranla 7/30 üniversiteden; "Laboratuvar cihaz alım giderleri ve Canlı hayvan ve yem alım giderleri" \%16,7 oranla 5/30 üniversiteden; "Kongre Katılımları" \%10 oranla 3/30 üniversiteden; “Temsil ağırlama giderleri ve Bakım onarım giderleri” \%6,7 oranla 2/30 üniversiteden; "Mamul Mal Alımları, Tercüme giderleri ve Panel düzenleme giderleri” \%3,3 oranla 1'er üniversiteden destek almaktadır.

Yükseköğretim kurumlarının harcama kalemlerinin çeşitlilik göstermesi, üniversitenin sermayesine, gelirlerine ve elde ettiği bilimsel çıktılara bağlıdır. Üniversitelerin döner sermayesi ve aktifliği oranında projeye harcadığı ödenek ve kalem miktarı çeşitlilik kazanmaktadır.

Dağılıma bakıldığında BAP Projeleri vasıtası ile en çok "seyahat giderleri, sarf tüketim ve malzeme giderleri, hizmet alım giderleri ve bilgisayar yazılım giderlerine” ihtiyaç giderimi sağlanmıştır. Görünen o ki, bilimsel faaliyetlerin gerçekleştirilmesi adına en çok ihtiyaç kalemleri Türkiye'de altı çizilenlerdir. İhtiyaç kalemlerinin fazlalığı, bölümlerin ve araştırmacıların farklı sektör ve alanlarda araştırmalar yaptıklarını belgelemektedir. Kalem sayısı azaldıkça ve bir kaleme yoğunlaştıkça ise, BAP vasıtasıyla alınan desteklerin sadece belirli alanlarda yapıldığını dile getirebiliriz.

\section{BAP Projeleri Süreleri}

Yükseköğretim kurumlarının BAP projelerini bitirmek için verdiği süre dağılımı tablo 10'da gösterilmiştir.

Tablo 10.

BAP Projeleri Süreleri

\begin{tabular}{lll}
\hline Proje Süresi Aralı̆̆ & $\mathbf{f}$ & $\mathbf{\%}$ \\
\hline $0-36 \mathrm{Ay}$ & 22 & 73,3 \\
\hline $12-36 \mathrm{Ay}$ & 2 & 6.7 \\
\hline $18-36 \mathrm{Ay}$ & 2 & 6,7 \\
\hline $24-36 \mathrm{Ay}$ & 2 & 6,7 \\
\hline Belirtilmemiş & 2 & 6,7 \\
\hline TOPLAM & $\mathbf{3 0}$ & $\mathbf{1 0 0}$ \\
\hline
\end{tabular}


Türkiye'de yükseköğretim kurumları tarafından desteklenen BAP projeleri, ek süreler dâhil olmak üzere, en çok 36 ay içerisinde tamamlanmaktadır. Tez projeleri için verilen süreler, yetkili birimler tarafından tezler için verilen yasal ek süreleri kapsayacak şekilde uzatılabilmektedir (YÖK, 2016). Bu görüş, enstitüler ve BAP komisyonlarının alacağı kararlara bağlıdır.

Tablo 10'da yükseköğretim kurumlarından 2000 yılı öncesinde kurulan 30 üniversitenin BAP projeleri süreleri görüldügü üzere BAP projelerinin \%73,3 gibi büyük bir bölümü "0-36 ay" zaman diliminde gerçekleştirilmektedir. Araştırma projelerinin büyük bir kısmı, ek süre dâhil olmak üzere, 3 yıl (36 ay) gibi bir sürede sonlandırılır. Bununla beraber, araştırma projelerinin içeriklerine, niteliklerine ve gerçekleştirilme sürelerine göre farklı zaman dilimlerinde de bitirilebilir (Örnek: 6 ay, 12 ay, 24 ay).

Araştırma bulgularına göre, üniversitelerin \%6,7 gibi oranlarla 2 tanesi 12-36 ay arasında; 2 tanesi 18-36 ay arasında; 2 tanesi de 24-36 ay arasında projelerinin sonuçlandırılmasını beklemektedir. Bununla beraber, \%6,7 gibi bir oranla 2 üniversite de proje sürelerini belirtmemiştir. Proje sürelerinin akademisyenler nezdinde sınırlı olması, araştırmacıların projelerini planlı bir şekilde yapmasına, işlerini aksatmamasına da yardımcı olmaktadır. Aynı zamanda, dönem dönem sunulan ara raporlar ile de bilimsel araştırmanın diriliği sağlanmaktadır.

\section{Akademisyenlerin BAP Projeleri Başvuru Hakları}

Yükseköğretim kurumlarında akademisyenlerinin BAP projeleri başvuru hakları dağılımı tablo 11'de gösterilmiştir.

\section{Tablo 11.}

BAP Projeleri Başvuru Hakları

\begin{tabular}{lll}
\hline Başvuru Hakki & f & $\mathbf{\%}$ \\
\hline 1 & 9 & 30 \\
\hline 2 & 6 & 20 \\
\hline 3 & 5 & 16,7 \\
\hline 4 & 1 & 3,3 \\
\hline Belirtilmemiş & 9 & 30 \\
\hline TOPLAM & $\mathbf{3 0}$ & $\mathbf{1 0 0}$ \\
\hline
\end{tabular}

Tablo 11'de gösterilen akademisyenlerin BAP projeleri başvuru hakları dağıll- 
mına bakıldığında; sadece 1 bilimsel araştırma projesine başvuru yapma hakkına sahip akademisyenler \%30 oranla 9 üniversite bünyesinde yer almaktadırlar. Bununla beraber, \%20 oranla 2 projeye başvurabilen akademisyenlerin olduğu üniversite sayısı 6; \%16,7 oranla 3 projeye başvuran akademisyenlerin olduğu üniversite sayısı 5 iken; 4 projeye başvuran \%3,3 oranlı üniversite sayısı ise sadece 1'dir. Araştırma kapsamında \%30 gibi büyük bir oranla 9 üniversite de akademisyenlerin kaç adet projeye başvuracağını belirtmemiş, bu durumun BAP komisyonlarınca karara bağlanacağını dile getirmiştir.

Küçüksüleymanoğlu (2007)'na göre, yükseköğretim kurumlarında görev yapan öğretim elemanlarının son yıllarda birçok sorun yaşadığı dile getirilmektedir. Proje gerçekleştirmedeki sayı sınırlaması, bilimsel araştırma ve geliştirmenin önünde bir set olarak durmaktadır. Bilim insanı yapmak istediği ve önceden tasarladığı projeleri destek bulamadığ için yapamıyorsa bu durum bilimin sınırlılığı ve yükseköğretim kurumlarının yetersizliğidir. Fakat maddi imkân yetersizliği ve başvuruların fazlalığından dolayı, yükseköğretim kurumları başvuru sayısında sınırlamalara gitmek mecburiyetindedir.

\section{Yılında En Fazla BAP Desteği Alan Üniversiteler}

Türkiye'deki yükseköğretim kurumlarından en fazla BAP desteği alan 25 üniversite tablo 12'de gösterilmiştir (TÜBİTAK, 2016).

\section{Tablo 12.}

2016 Yllında En Fazla Destek Alan İlk 25 Üniversite

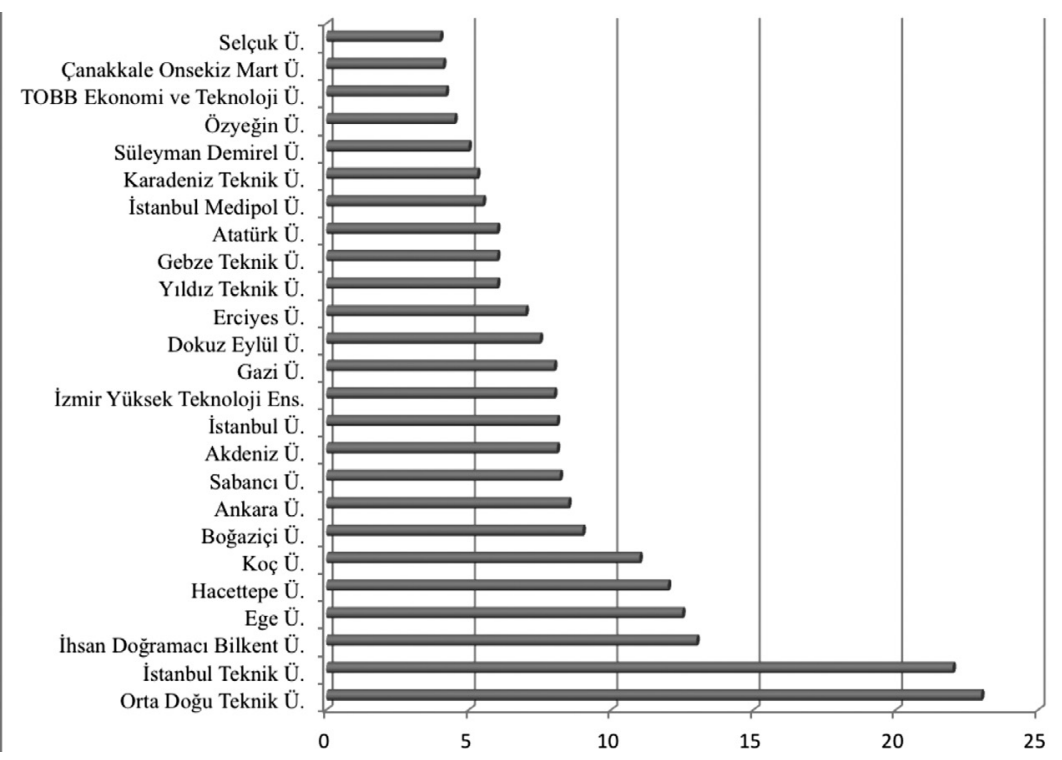


Üniversiteler; eğitim ve öğretim, bilimsel araştırmalar ve yayınlar icra eden kurumlar olarak tanımlanmaktadır. Bu işlevleri gerçekleştirmek üzere kurulan yükseköğretim kurumlarının aynı zamanda toplumda yaşanan sorunlara da çözüm üretmesi beklemektedir. Toplumlar, yükseköğretim kurumlarını yukarıda saydığımız temel görevleri, kendi ihtiyaçlarını en iyi şekilde karşılamak üzere ortaya çıkarmışlardır (Başkan, 2001). Bu vesile ile Türkiye'deki yükseköğretim kurumları çeşitli araştırma faaliyetlerinde bulunmakta ve bu araştırma faaliyetlerinden bazı yükseköğretim kurumları daha büyük bütçeler almaktadır. Türkiye'de eğitim öğretim hizmeti veren ve 2000 yılı öncesinde kurulan 30 üniversitenin BAP koordinatörlüklerinin incelenmesi sonunda, 2016 yılı itibariyle en çok BAP desteği alan üniversiteler tablo 12'de gösterilmiştir. Buna göre Ortadoğu Teknik Üniversitesi yaklaşık 23 milyon TL ile birinci, İstanbul Teknik Üniversitesi yaklaşık 22 milyon TL ile ikinci, Bilkent Üniversitesi de yaklaşık 13 milyon TL ile üçüncü en büyük bütçeyi almışlardır. Dikkat çeken bir diğer husus ise, teknik üniversitelerin, BAP projelerinden daha fazla istifade etmesidir. Bu bulgulara göre bilimsel araştırmaların, teknolojik alanda ve sanayi alanında daha fazla yoğunlaştığını dile getirebiliriz.

\section{Destek Kararı Verilen BAP Projelerinin Yıllara Göre Dağılımı}

Türkiye'deki yükseköğretim kurumlarında destek kararı verilen BAP projelerinin yıllara göre dağılımı tablo 13’te verilmiştir (TÜBİTAK, 2016).

\section{Tablo 13:}

Destek Kararı Verilen BAP Projelerinin Yıllara Göre Dağılımı

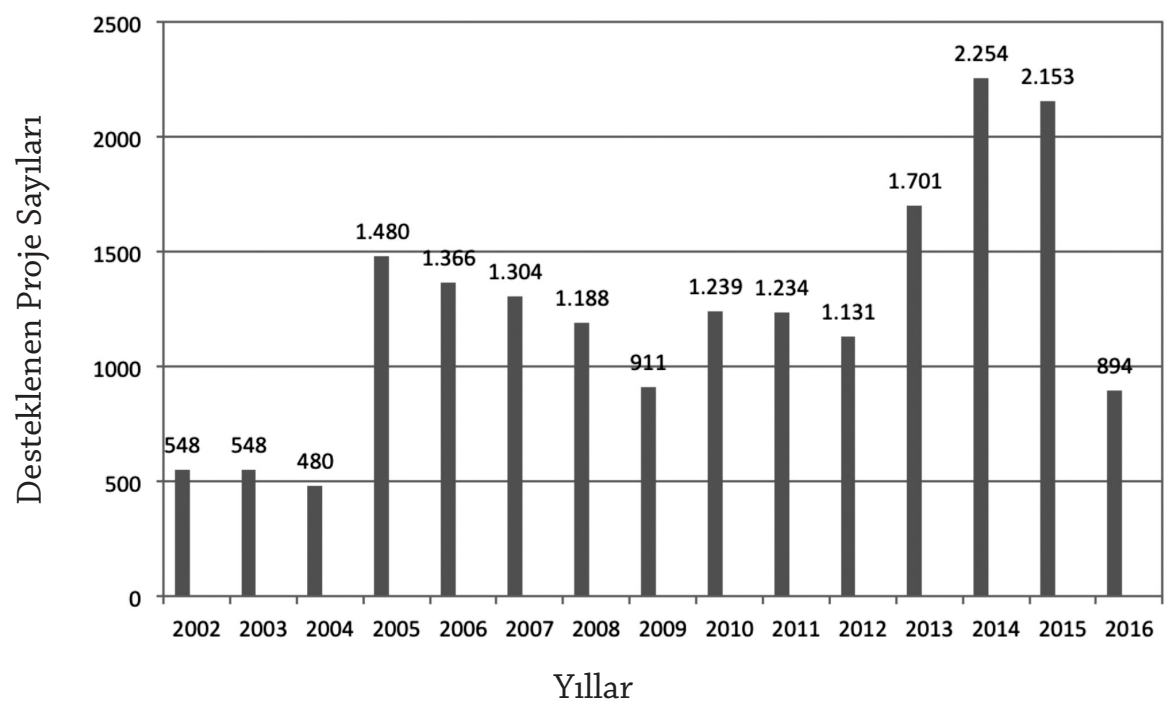


Üniversiteler veya diğer bir ifade ile yükseköğretim kurumları, geçmişten günümüze kadar içinde bulunduğu toplumları çağına göre etkileyen ve toplumlardan etkilenen en önemli kurumlardan birisi olmuştur. Yükseköğretim kurumlarının temel görevi; bilime katkı sağlamak, üretilen bilgileri teknolojiye dönüştürmek ve bu vesile ile toplumu mutlu ve ferah kılmaktır. Günümüz dünyasında, Türkiye'de yükseköğretim kurumlarından beklentiler değişmiş, bu kurumlar yalnızca bilimsel çalışmalar gerçekleştiren ve üstün beyinler yetiştiren kurumlar olmaktan çıkarılmış, birer işletme gibi verim sağlayarak çalışması beklenilen kurumlar haline gelmişlerdir. Kaynakların azaldığı ve kaynak arayışının fazlalaştığı dünyamızda, verim ve etkili kullanım yöntemleri ön plana çıkarılmış ve bu durumlar yönetimde değişiklikler meydana getirmiştir. Daha anlaşılır bir ifade ile, toplumlar artık yükseköğretim kurumlarını ya da üniversiteleri sadece bilime katkıda bulunan yerler olarak görmemektedir. Bu sebeple, yükseköğretim kurumlarından beklenen görev ve uygulamalar günümüzde sorgulanmaya başlanmıştır (Meray, 1971, s. 15). Üniversitelerin yetiştirdiği bilim insanlarının her geçen gün azalan kaynaklar karşısında; yeni projeler ile araştırmalar ile imkânları zorlamaları ve bilime katkı sağlamaları beklenmektedir.

TÜBİTAK ARDEB tarafından destek kararı verilen projelerin yıllara göre dağılımı tablo 13'te verilmiştir. Buna göre en fazla destek kararı, 2014 yılında 2.254 proje sayısı ile alınmıştır. Bu tarihi, 2015 yılı 2.153 ve 2013 yılı 1.701 proje sayısı ile izlemektedir. Sayısal olarak en az destek oranı ise 2003 yılında 338 proje ile gösterilmiştir. 2005 ve 2012 ylları arasında proje sayılarında dalgalanma mevcut iken, 2013 yılı ve sonrasında artış gözlenmiştir.

\section{Sonuç ve Değerlendirme}

Türkiye'de eğitim öğretim hizmeti veren ve 2000 yll öncesinde kurulan 30 üniversitenin BAP koordinatörlüklerinin ve çalışmalarının incelenmesi sonunda gerçekleştirilen araştırma; yükseköğretim kurumlarındaki bilimsel araştırma projelerini ve yöntemlerini analiz etmek amacıyla gerçekleştirilen bir değerlendirme niteliğindedir.

Odabaşı (2016)'nın tanımıyla üniversiteler, yenilik unsurlarının temelini atmada, yaratıcı bilgilerin üretilmesi ve yayılması adına hep olduğu gibi ön sıralarda yer almalıdır. Hızla değişen çevre koşulları, üniversitelerin stratejik ve işlevsel işler yapmalarını yoğun bir şekilde etkilemektedir. Aynı zamanda girişken olmaya da teşvik etmelidir. Araştırma kapsamında incelenen yükseköğretim kurumlarındaki bilimsel araştırma desteklerini veren BAP koordinatörlüklerinin kuruluş yıllarına bakıldığında; koordinatörlüklerin yoğun olarak 2002 yılında ve sonrasında kurul- 
duğu görülmektedir. Bu durumun sebebi özellikle çıkarılan kanun ve yönetmeliklerin yarattığı oluşturma zorunluluğudur. Bununla beraber bilimsel araştırma desteği vermek için BAP koordinatörlüklerini kanunlar öncesinde oluşturan üniversitelerin sayısı bir hayli azdır. Fakat bu üniversitelerin hem web siteleri hem faaliyet raporları hem de BAP içerikleri 2002 yılı ve sonrasında kurulan BAP birimlerine göre daha nitelikli ve zengindir.

BAP komisyonlarında her fakülteden temsil niteliğinde öğretim üyelerinin BAP komisyonunda bulunması, komisyon sayısının değişkenlik göstermesine sebebiyet verecektir (Örnek: 4 fakültesi olan bir üniversite ile 7 fakültesi olan bir üniversitenin komisyon üye sayllarının değişkenlik göstermesi normaldir). Yükseköğretim kurumlarının komisyon sayılarında dikkat çeken bir diğer özellik ise bazı üniversitelerin komisyon sayılarının (başkan dâhil) 12'den fazla olmasıdır. Resmi Gazete (2016)'de yayımlanan yönetmeliğin aksine böyle bir durum ile karşılaşılmasının sebebi, fakülte çeşitliliği, gereksinimler ve BAP komisyonlarının faaliyet alanlarının çokluğu ve proje başvurularının yoğunluğudur. Bu durumdaki üniversiteler, genellikle BAP kapsamında aktif üniversitelerdir. Yönetmelikte madde açıtır: "Rektör veya görevlendireceği bir rektör yardımcısı başkanlı̆̆ında senatonun önerisiyle rektör tarafından görevlendirilen, en az yedi en çok on bir öğretim üyesinden oluşan bir komisyon kurulur." ifadesi yer almaktadır (Resmi Gazete, 2016).

Üniversitelerin BAP birimlerinin web sitelerinin aktif olması önemlidir. Bilimsel bir araştırma yapmak isteyen akademisyenler, öncelikle bilimsel araştırmanın ne olduğunu öğrenecek, araştırmasını gerçekleştirmek için nelere ihtiyacı olduğunu düşünecek ve harekete geçmek ve destek almak için bir proje hazırlamak isteyecektir. Bunu gerçekleştirmek için ilk bakacağı yer, dâhil olduğu yükseköğretim kumrunun BAP koordinatörlüğünün web sitesidir. Eğer kurumun web sitesi aktif değil ise, proje ve bilimsel araştırma konusunda personelinize destek olamazsınız. $\mathrm{Bu}$ durum, bilim için bir sınırlılık ve bilimsel araştırmacı için ise kayıptır. Araştırma bulgularında incelenen yükseköğretim kurumlarının BAP koordinatörlüklerinin web sayfalarının büyük bir çoğunluğunun aktif olması sevindiricidir.

Bilimsel araştırmaların faaliyetlerinin çoğalması, proje çalışmalarının hızlanması ve bilimsel çalışmalara verilen desteklerin çeşitliliğinin artması kadar, sonuçlanan proje çıktılarının paylaşılması, verilerinin analiz edilmesi ve yaşanılan topluma mal edilmesi de önem arz etmektedir. Yükseköğretim kurumlarının BAP koordinatörlüklerinin faaliyet raporlarının paylaşıma açık olması "şeffaflık ve hesap verilebilirlik" açısından önemlidir. Zira gerçekleştirdiği faaliyetleri ve destek verdiği projeleri kamuoyu ile paylaşan üniversiteler güvenilir üniversiteler statüsündedir. Genel olarak araştırma kapsamına alınan üniversitelerin BAP faaliyet raporlarını 
internet sitelerinde yayınlamaları Türkiye'deki üniversitelerin bu konuda şeffaf olduklarının göstergesidir. Bu faaliyet raporları, 1998 ve sonrasını kapsayacak şekilde, özellikle 2009 ve sonrasında düzenli olarak kamuoyu ile paylaşılmaktadır.

Üniversitelerde, BAP birimlerinin destek verdiği proje başlıkları çeşitlilik gösterebilmektedir. Bunun sebebi, üniversitelerin bünyesinde bulundurduğu bölümlere uygun proje başlıkları düzenlemesidir. Örnek verecek olursak; bünyesinde ziraat fakültesi olmayan bir üniversitenin bahçe makineleri ile ilgili proje başlığı açması ne kadar gereksiz ise; bünyesinde eğitim fakültesi olan ve sosyal beşeri bilimler ile ilgili proje başlığı olmayan üniversite BAP koordinatörlüğünün geçerliliğinin de yeniden gözden geçirilmesi önemlidir.

2002 yılından günümüze kadar hızla gelişim gösteren ve araştırmacılara verdiği desteğin önemi yeni yeni anlaşılmaya başlanan BAP projeleri, yıllar geçtikçe yükseköğretim kurumlarında çeşitlilik kazanmaya başlamıştır; bununla beraber, proje kapsamları da hızla büyümekte ve isimleri de çeşitlilik kazanmaktadır. Araştırma sonuçlarına göre; Türkiye'deki yükseköğretim kurumlarında en çok verilen ve bilimsel araştırmacılar tarafından en çok başvurulan destek başlıkları şunlardır: "Lisansüstü tez projeleri, Bilimsel AR-GE için altyapı destek projeleri, Hızlı destek projeleri, Bilimsel etkinliklere katılım ve düzenleme desteği, Fikir mülkiyet ve patent desteği ve Uluslararası araştırma projeleri”. Bu proje başlıklarının haricinde 46 çeşit proje içeriği araştırmacılar için mevcut durumdadır.

Teknolojinin bir hediyesi olan bilgisayar ve internetin olanaklarını en iyi şekilde kullanan yükseköğretim kurumları, bilimsel araştırma projelerini de çevrimiçi olarak değerlendirmekte ve başvuruları bu yolla kabul etmektedir. Araştırma kapsamında; üniversitelerin büyük bir çoğunluğu başvuruları çevrimiçi olarak değerlendirmekte ve neticede araştırmacılara zaman kazandırmaktadır. Bu durum, teknolojinin bilimsel araştırma projelerine bir desteği olarak nitelendirilebilir.

Online olarak yapılan proje başvurularının yılın her döneminde kabul ediliyor olması büyük bir avantajdır. Bilimsel araştırmacı, nitelikli bir proje hazırlarken “acaba süreyi yetiştirebilecek miyim?” düşüncesi ile projesine zarar vermemiş olacaktır. Bununla beraber araştırma kapsamında yılda belirli (yılda 1 ya da yılda 2 veyahut 3) dönemlerde yapilan proje başvuru sistemleri de mevcuttur. Bu sistem ile araştırmacının projesinin niteliğinin düşmesi aşikârdır.

Bir bilim insanının proje oluşturmasındaki ilk amaç, bilimsel araştırmasını gerçekleştirmek için maddi kaynak bulma çabasıdır. Bu neticede, bilimsel araştırmalar için projeler oluşturulmakta ve bu projeler çeşitli bütçe harcama kalemleri ile desteklenmektedir. Bu bütçe kalemlerinin en çok gereksinim duyulanları araştırma 
sonuçlarına göre sırasıyla şunlardır: "Seyahat giderleri, Sarf ve tüketim malzemesi giderleri, Hizmet alım giderleri, Bilgisayar, yazıcı vb. donanım ve yazılım giderleri ve Makine teçhizat giderleri." Bu proje başlıklarının yanında, araştırmamızın sonuçlarına göre, "21 adet" proje bütçesi harcama kalemi, bilimsel araştırmacıların başvurusu için hazırdır.

Araştırma sonuçlarına göre, üniversitelerdeki bilimsel araştırma destekleri, sınırlı süreleri kapsar ve maksimum 3 seneyi geçemez. Proje süreleri, niteliği ve hizmet alanına göre, 0 ile 36 ay arasında değişiklik gösterebilir. Bunun yanında, proje sürelerinin sınırlı olması bilimsel araştırmacıyı sonuca ulaşmaya güdüler.

Bulgulardan elde edilen sonuçlara göre, bilimsel araştırmacıların yükseköğretim kurumlarından aldıkları proje desteği sayıları sınırlandırılmıştır. Genellikle üniversiteler bir projeyi bitirmeden diğer projeye başlamaya izin vermez iken, bu durum proje başlığı, içeriği ve destek miktarına göre değişkenlik gösterebilmektedir. Örneğin; altyapı destek projesi yürütücüsü olan bir akademisyen, aynı zamanda güdümlü bir projeye ya da farklı bir altyapı destek projesine yürütücü olamaz iken, lisansüstü tez yürütücüsü olabilmektedir. Bu durum üniversitelerin özerk ve bağımsız BAP yönergelerindeki maddelere göre düzenlenmektedir. Fakat hızla gelişen bilgi çağı ışı̆̆ında, bilimsel gelişmelerin niteliklerinin artması adına bilimsel araştırma faaliyetleri gerçekleştirmek isteyen akademisyenlerin proje başvuru sayısı limitleri kaldırılmalıdır. Bu durum, araştırmacıların yeni projelere yoğunlaşmasina ket vurmakta ve onları frenlemektedir.

\section{Politika ve Uygulama Önerileri}

Dünyada ve Türkiye'de bilim ve sanat alanında yol kat edilmek isteniyorsa, araştırmacı ve girişken bilim insanı yetiştirilmesi ön koşuldur. Unutmayalım ki, "hayal etmeden düşünemez, düşünmeden yapamaz, yapmadan da sonuçlara vâkıf olamayız". Araştırma bulguları genel olarak incelendiğinde; her üniversitenin BAP koordinatörlükleri yeniden yapılanma sürecine gitmelidir (kuruluş yapıları, web siteleri, BAP türü çeşitliliği, çevrimiçi imkânlar, başvuru dönemleri, bütçe harcama kalemi çeşitliliği, başvuru süreleri, akademisyen başvuru hakları). Komisyon üye sayılarındaki artış, nitelikli toplantılara sebebiyet verecek ve daha geçerli kararların alınmasını sağlayacaktır. BAP koordinatörlükleri kullanımındaki web adreslerinin güncel tutulması ve isteyenlerin istedikleri zaman bilimsel araştırmalar konusunda tüm verilere ulaşması sağlanmalıdır. Bu durum, üniversitelerin güvenilirliğini ve hesap verilebilirlik değerini yükseltecektir. BAP biriminin çalışmalarını takip eden ve desteklediği proje sayılarını inceleyen bir bilim insanı; proje çeşitliliğini gördüğünde, 
kendisi de aktif bir projede yer almak ya da bir projeye imza atmak isteyebilir. Bu yüzden farklı fikirlere uygun projeler oluşması için proje ismi çeşitliliği önemlidir. Projelerin tüm üniversitelerde çevrimiçi olarak başvurularının alınması çalışmaları hızlandırılmalıdır. Böylece bilimsel çalışmalarda zaman tasarrufu sağlanacak ve araştırmacılara zaman kazandırılacaktır. Aynı zamanda, bilimsel araştırmalar için verilen proje desteklerine bir başvuru tarihi konulması yanlıştır. Bilim insanı istediği zaman ve yılın her dönemi proje başvurusu yapabilmelidir. Proje harcama bütçe kalemleri proje yazarlarına ve araştırmacılara en anlaşılır şekilde anlatılmalı, proje yazma amacının sadece maddi destek almak değil, projeyi bitirmek ve bilimsel bir veri ortaya koymak için kaynakların tedarik edilmesini sağlamak olduğu açıkça ifade edilmelidir. BAP projelerinin süreleri, içerikleri komisyonlarca ayarlanmalı ve ara raporlamalar ile takip edilmelidir. Son olarak, araştırmacıların proje başvuru hakkı sınırlamaları ivedi bir şekilde kaldırılmalı ve nitelikli proje yazarları ve bilim insanlarının önü açılmalıdır. Günümüzde üniversitelerin sadece bilim üreten değil, ürettiği bilimi hizmet alanında kullanan kurumlar olması ve yetiştirdiği insanların girişimci bir yapıya sahip olması esas olmalıdır. 


\title{
Scientific Research Supports in Higher Education Institutions
}

\author{
İsmail Erol \\ Yusuf Alpaydin
}

\section{Introduction}

The rapid globalization of the world, the developments in information technologies and the easy sharing of scientific knowledge have helped to qualitatively and quantitatively improve scientific research. Thus, the search for resources, budget and financial support for scholarly research in higher education institutions of academicians has diversified.

As with international academic projects, scientific research projects (BAP) are given to researchers in different disciplines by prioritizing them in accordance with the national science and technology policies, the goals of the nation and the country, or the science policies determined by the higher education institutions. It is essential that BAP projects contribute to the development of technological, economic, artistic, social, cultural and research policies.

The $\mathrm{R} \& \mathrm{D}$ expenditure of the countries varies according to the sources of finance and the sectors that implement it. In developed countries such as the US, Japan, China, Germany, the UK and France, it appears that there is a significant share of the private sector, both in the financing of $\mathrm{R} \& \mathrm{D}$ spending and in the sectors that realize it. In the OECD and EU countries, the average share of private sector total R \& D activities is higher than that of the public sector. In countries such as Greece, Turkey, Poland, New Zealand in the developing countries group, it is seen that the participation of the government and especially higher education in $\mathrm{R} \& \mathrm{D}$ activities is high.

@

Lecturer, Namık Kemal University. ismailerol59@nku.edu.tr

Assist. Prof., Marmara University. yusuf.alpaydin@marmara.edu.tr 
Scientific researches carried out at universities are financed by scholarship allowances from the treasury revenues of the universities and scholarships from the revolving fund revenues of the universities. In this context, the sufficiency of the expenditures of scientific research in general, and the research projects in the budgets of universities in particular, is of great importance in terms of enabling scientific research and ensuring social and economic development with the results obtained.

In Turkey, most of the scientific publications and research activities that are increasing with the developing economy are realized in universities. Higher education institutions in Turkey make up 91\% of scientific publications in the country and Turkey ranks first in Europe with this ratio.

"Scientific Research Projects" are guaranteed by regulations in higher education institutions. The purpose and scope of the regulations related to scientific research projects, evaluation, acceptance and support of scientific research project proposals carried out in higher education institutions, implementation, monitoring, evaluation of results, public announcement and related procedures and principles shall be determined. Outputs of scientific research projects and academic studies are guided by studies and practices in higher education institutions. The content, scope, scope of scientific research support, application period, project diversity and commissions of researchers in higher education institutions are not fully understood by researchers. A study explaining scientific research support in higher education institutions in Turkey has not yet been done. This study aims to identify, examine, assess and question the contents of scientific research support of universities in terms of understanding the research policies and scientific development infrastructure in the country and to reveal the focuses. The findings of the study will also provide guidance to academicians who wish to perform BAP.

\section{Method}

73 universities established in Turkey before and in the year 2000 constitute the universe of research. The sample of the study included 30 universities with access to BAP data. This research was designed in accordance to a descriptive screening model. Screening models are research approaches that aim to describe the past or present as it exists. Any change of circumstances, no effort to influence is shown. Descriptive research; responding to the question of what is happening, trying to explain the events, objects, institutions, groups and various kinds. This allows them to understand and sort them as they are. In this research, scientific research supports in higher education institutions; the number of commission members, 
website access, activity report availability, scientific research support types, application types, application date ranges, budget items, support periods and the number of projects that academicians could apply for are included in the scope of the review. Content analysis techniques are used for this review. The content analysis technique is an analysis tool used extensively in social science studies. Messages that are called proofs of social communication are written documents or videotaped analysis. The content analysis expert is likened to a detective working with sensitive equipment on documents. In the first stage of content analysis, the data of the BAP units of 30 universities in our sample group were transferred to the computer files. Coding and categories are very important in content analysis. The generated categories should be very clear and the same results should be achieved when the data of the research is analyzed by another researcher. Opinions of field experts were obtained to ensure the reliability of the data. Data collected in the study was analyzed by means of a SPSS package program and percentages and frequencies were calculated. The method of frequency analysis is to detect the possibility of the numerical appearance of records with the simplest definition. The results of the frequency analysis are categorized according to the unit probability coded in the context and the order of importance of the items is given.

\section{Results and Conclusions}

Access to the activity reports of BAP units is easily achieved. It is seen that the number of project type changes between 2 and 15 for BAP units. Intensively supported types of projects are postgraduate dissertation projects, infrastructure support projects for scientific R \& D, rapid support research projects, participation and regulatory support for scientific activities. The study found that universities accepted BAP support applications online and were able to accept applications at any time of the year. When expenditure items are examined, service purchase expenses, travel expenses, computer and appointment expenses are more frequently encountered. When the BAP project duration is examined, it is seen that the projects usually last 12-24 months and the final reports are requested at the end of this period. Project support number limits vary between 1-3. In the research findings; higher education institutions have encouraged academicians to implement scientific research projects, that they have accepted the applicants online, and that they are linking to commissions within the institution. As a matter of fact, the number of project supporters is pushing the academicians to make a "single" project every year or every two years. 
When the years of establishment of the BAP coordinators that provide scientific research support in higher education institutions are examined; it is observed that the coordinatorships were usually established in 2002 or later. The reason for this is the necessity of establishing a BAP unit created by the laws and regulations issued. The presence of faculty members in every faculty in BAP commissions in higher education institutions causes the number of commissions to vary. (Eg it is normal for a university with 4 faculties and 7 faculties to have varying numbers of committee members). The web sites of BAP units of higher education institutions are active. An academician who wants to conduct a scientific research will first want to learn what a scientific research is, to think about what it takes to carry out his research, and to put a project into action. It is also important that the scientific research activities increase, the acceleration of the project work and the increase of the diversity of the scientific study support, as well as the sharing of the resulting project outputs, the analysis of the data and the accountability. It is important in terms of transparency and accountability that the sharing of the activity reports of BAP units of higher education institutions is open. In universities, project titles supported by BAP units can vary. The reason for this is to organize project titles in accordance with the faculties and departments the universities have.

The BAP projects, which have developed rapidly from the year 2002 to the present day, have begun to diversify in higher education institutions over the years and the project scope has grown rapidly and their names have diversified. The topics most frequently consulted by researchers and supported by higher education institutions are: "Graduate thesis projects, infrastructure support projects for scientific R \& D, rapid support projects, participation and regulatory support for scientific events, intellectual property and patent support, and international research projects". Apart from these project titles, 46 kinds of project titles are open for the application of researchers. Higher education institutions that use computer and internet facilities in the best way accept scientific research projects online and evaluate applicants in this way. As a result of the research; it has emerged that a large majority of the universities evaluated BAP applications online and consequently gained time for researchers. It is also a great advantage that online project applications are accepted every month of the year. When preparing a qualified project, the researchers would not have harmed the project with the thought of "can I raise my time?" With this situation, there are also BAP project application systems that are carried out at certain times a year ( 1 per year, or 2 or 3 per year).

The first aim of a scientist in creatinga project is to seek financial support to carry out his research. As a result, projects are being created for scientific research and these projects are supported by various budget expenditure items in BAP 
units. According to the results of the research; The most needed items of these budget items are as follows: "Travel expenses, consumables expenditures, service purchase expenses, computer printers, etc. hardware and software expenditures, and machinery equipment expenditures." In the publication of these budget items, according to the results of our research, there are totally "21" project budget expenditure items.

According to the results of the research, BAP supports in universities cover a limited period and can not exceed a maximum of 3 years. Project duration may vary from 0 to 36 months depending on the nature and service area. This is due to the fact that the duration of the project is limited, the researcher is trying to reach a conclusion. Researchers have limited the number of project supports received from higher education institutions. Generally, universities do not allow you to start another project without finishing a project, which may vary depending on project title, content and amount of support.

The BAP coordinators should keep up-to-date web addresses open to use and ensure that those who want to access all the information about scientific research are able to. This will increase the credibility and accountability of universities. Universities should create project titles appropriate to all faculties and departments under the roof and prepare rich content supports. A scientist who follows the work of the BAP unit and studies the numbers of projects it supports, may want to take part in an active project when he sees the diversity of the project. Therefore, the diversity of project names is important for projects to lead different ideas. BAP projects should be accelerated to take online applications at all universities. This will save time for them and time for researchers. At the same time it is wrong to set a reference date range for project supports. The scientist should be able to apply for the project at any time and at any time of the year. The budget items of the project should be explained in the best way to the researcher; it should be clearly stated that it is to provide scientific data. The duration and contents of the BAP projects should be set by commissions and followed up with interim reports. Finally, the restriction of researchers' right to apply for a project should be lifted and qualified project writers and scientists must be opened.

\section{Kaynakça | References}

Ak, M. Z. \& Gülmez, A. (2006). Türkiye'nin uluslararası yayın performansının analizi. Akademik İncelemeler Dergisi, 1(1), 22-49.

Anadolu Üniversitesi BAP Birimi. (2017). BAP Nedir?. https://www.anadolu.edu.tr/arastirma/bilimsel-arastirma-projeleri/bap-nedir adresinden 11.03.2017 tarihinde edinilmiştir.

Baskan, G. A. (2001). Türkiye’de yükseköğretimin gelişimi. Gazi Üniversitesi Gazi Eğitim Fakültesi Dergisi, (1), 21-32. 
Bilgin, N. (2006). Sosyal bilimlerde içerik analizi teknikler ve örnek çalışmalar. Ankara: Siyasal.

Boğaziçi Üniversitesi Araştırma. (2017). BAP Komisyonu. http://www.arastirma.boun.edu.tr/_files/BAP\%20Komisyonu\%20\%C3\%87al\%C4\%B1\%C5\%9Fma\%20Y\%C3\%B6nergesi.pdf adresinden edinilmiştir.

Boz, M. (2011). Üniversitelerde bilimsel araştırma projelerinin (BAP) etkinliği ve mali yapısının incelenmesi: Çanakkale Onsekiz Mart Üniversitesi örneği. Yüksek Lisans Tezi. Çanakkale Onsekiz Mart Üniversitesi.

BTYPD Yönetmeliği. (2012). Tübitak bilim, teknoloji ve yenilik politikaları daire başkanlığının teşkilat, yetki ve sorumlulukları ile çalışma usul ve esaslarına ilişkin yönetmelik. http://www.tubitak.gov.tr/tubitak_content_files //mevzuat/yonetmelik/yonetmelik_V_2.pdf adresinden 20 Kasım 2015 tarihinde edinilmiştir.

Bulun, M. Gülnar, B. \& Güran, S. (2004). Eğitimde mobil teknolojiler. TOJET: The Turkish Online Journal Of Educational Technology, 3(2), 165-169.

Çalışkan, M. İ. (2006). AB sürecinde Türkiye ile AB ülkeleri eğitim istatistiklerinin karşılaştırması. Türk Eğitim Bilimleri Dergisi, 4(4), 375-394.

Fraenkel, J., R., \& Wallen, N. (2005). How to design and evaluate research in education. New York: Mc Graw Hill.

Gasset, J. O. (2014). Mission of the University (Vol. 17). Routledge.

Göker, S. D. \& Gündüz, Y. (2017). Eğitim denetimi sürecinde hesap verebilirlik ve şeffaflı uygulamaları. Ondokuz Mayıs Üniversitesi Eğitim Fakültesi Dergisi, 36(1), 83-94.

Günay, D. (2001). Üniversitenin niteliği, akademik özgürlük ve üniversite özerkliği. Policy, 14(1), 37-44.

İskender, E. \& İskender, H. Y. (2016). Akademik Girişimcilik Bağlamında TÜBİTAK Desteklerinin Dağılımının İncelenmesi.http://acikerisim.hakkari.edu.tr:8080/xmlui/handle/123456789/194?show=full adresinden 28.04.2017tarihinde edinilmiştir.

Kaptan, S. (1998). Bilimsel araştırma ve istatistik teknikleri. Ankara: Tekışık Web Ofset.

Karasar, N. (2010). Bilimsel araştırma yöntemi. Ankara: Nobel.

Krippendorff, K. (2004). Content analysis: An introduction to its methodology. Thousand Oaks, CA: Sage.

Küçüksüleymanoğlu, R. (2007). Eğitim fakültesi öğretim elemanlarının tükenmişlik düzeyleri. Eğitim Araştırmaları, 7(28), 102-112.

Meray, S.L. (1971). Üniversite kavramları ve modelleri. Siyasal Bilgiler Fakültesi Dergisi. 26(1), 1-54.

Moed, H. F. (2006b). Bibliometric rankings of world universities. CWTS Report, 1.

Odabaşı, Y. (2006). Değişimin ve dönüşümün aracı olarak girişimci üniversite. http://acikerisim.lib.comu.edu. tr:8080/xmlui/handle/COMU/974 adresinden 01.05.2017 tarihinde edinilmiştir.

OECD. (2010). Main science and technology indicators (MSTI). http://www.oecd.org/dataoecd/9/44/41850733.pdf adresinden 02.10.2017 tarihinde edinilmiştir.

Resmi Gazete. (2016). Yükseköğretim Kurumları Bilimsel Araştırma Projeleri Hakkındaki Yönetmelik. http://www.resmigazete.gov.tr/eskiler/2016/11/20161126-8.htm adresinden 10.03.2017 tarihinde edinilmiştir.

Shenhar, A. J. Dvir, D. Levy, O. \& Maltz, A. C. (2001). Project success: a multidimensional strategic concept, Long Range Planning, 34(6), 699-725.

Tanrıkulu D. (2009). Yükseköğretime erişimin arz ve giriş koşulları açısından değerlendirilmesi ve Türkiye için çözüm önerileri, DPT Uzmanlık Tezi, Ankara.

Tuzcu, G. (2003). Lisansüstü öğretim için yurtdışına öğrenci göndermenin planlanması, Milli Eğitim Dergisi. Sayı, 160 (1), 314-339.

TÜBİTAK. (2010). Ulusal Destek Programları. https://www.tubitak.gov.tr/tr/ destekler/sanayi/ulusal-destek-programlari/1507/icerik-formlar-0 adresinden 11.03.2017 tarihinde edinilmiştir.

TÜBİTAK. (2016). Akademik Destek İstatistikleri. http://www.tubitak.gov.tr/tr/destekler/akademik/ulusal-destek-programlari/icerik-akademik-destek-istatistikleri adresinden 13.10.2017 tarihinde edinilmiştir.

TÜBİTAK. (2016). Araştırmacı Bilgi Formu. https://arbis.tubitak.gov.tr/pages/ bilgipinari/user/istatistikForm3.jsp?recno $=7$ adresinden 10.03.2017 tarihinde edinilmiştir.

TÜBİTAK. (2017). AR-GE Faaliyetlerimiz. http://www.tubitak.gov.tr/sites/default/files/281/ ardeb_stat_2017_1. pdf adresinden 13.10.2017 tarihinde edinilmiştir. 
UNDP (United Nations Development Programme). (1998). Glossary of key terms. governance for sustainable human development, p.1. http://magnet.undp.org/policy/glossary.htm adresinden 13.10.2017 tarihinde edinilmiştir.

Vildan, A. \& Karacan, H. (2009). Abant İzzet Baysal Üniversitesi web sitesi kullanılabilirlik analizi. International Journal of Informatics Technologies, 2(2), 33-38.

Yıldırım, A. \& Şimşek, H. (2006). Sosyal bilimlerde nitel araştırma yöntemleri (5. Baskı). Ankara: Seçkin Yayıncılık.

Yıldırım, A., \& Şimşek, H. (2013). Sosyal bilimlerde nitel araştırma yöntemleri (9. baskı). Ankara: Seçkin Yayıncılık.

Yıldırım, C. (1997). Bilimsel düşünme yöntemi: yazılar, bildiriler, tartışmalar. Ankara: Bilgi Yayınevi.

Yükseköğretim Kurulu. (2007). Türkiye’nin yükseköğretim stratejisi. T.C. Yükseköğretim Kurulu.

Yükseköğretim Kurulu. (2003). Türk yükseköğretiminin bugünkü durumu. Ankara.

Yükseköğretim Kurulu. (2016). Yeni BAP yönetmeliği. http://www.yok.gov.tr/web/guest/icerik//journal_content/56_INSTANCE_rEHF8BIsfYRx/10279/31671078 adresinden: 13.10.2017 tarihinde edinilmiştir.

Yücel, İ. H. (1997). Bilim-teknoloji politikaları ve 21. Yüzyılın toplumu. Ankara: DPT.

\section{Ekler}

Çalışma evreni olarak Türkiye'de eğitim öğretim hizmeti veren 2000 yılı ve öncesinde kurulan (1933-1999) 30 üniversite aşağıda belirtilmiştir:

\section{İNCELENEN ÜNIVERSITELER}

\begin{tabular}{llll}
\hline $\mathbf{1}$ & İstanbul Üniversitesi & $\mathbf{1 6}$ & Erciyes Üniversitesi \\
\hline $\mathbf{2}$ & İstanbul Teknik Üniversitesi & $\mathbf{1 7}$ & Akdeniz Üniversitesi \\
\hline $\mathbf{3}$ & Ankara Üniversitesi & $\mathbf{1 8}$ & Dokuz Eylül Üniversitesi \\
\hline $\mathbf{4}$ & Ege Üniversitesi & $\mathbf{1 9}$ & Gazi Üniversitesi \\
\hline $\mathbf{5}$ & Karadeniz Teknik Üniversitesi & $\mathbf{2 0}$ & Marmara Üniversitesi \\
\hline $\mathbf{6}$ & Atatürk Üniversitesi & $\mathbf{2 1}$ & Trakya Üniversitesi \\
\hline $\mathbf{7}$ & Hacettepe Üniversitesi & $\mathbf{2 2}$ & Ylldı Teknik Üniversitesi \\
\hline $\mathbf{8}$ & Anadolu Üniversitesi & $\mathbf{2 3}$ & Abant İzzet Baysal Üniversitesi \\
\hline $\mathbf{9}$ & Çukurova Üniversitesi & $\mathbf{2 4}$ & Balıkesir Üniversitesi \\
\hline $\mathbf{1 0}$ & Dicle Üniversitesi & $\mathbf{2 5}$ & Celal Bayar Üniversitesi \\
\hline $\mathbf{1 1}$ & Cumhuriyet Üniversitesi & $\mathbf{2 6}$ & Çanakkale Onsekiz Mart Üniversitesi \\
\hline $\mathbf{1 2}$ & İnönü Üniversitesi & $\mathbf{2 7}$ & Kocaeli Üniversitesi \\
\hline $\mathbf{1 3}$ & Ondokuz Mayıs Üniversitesi & $\mathbf{2 8}$ & Muğla Sitkı Koçman Üniversitesi \\
\hline $\mathbf{1 4}$ & Selçuk Üniversitesi & $\mathbf{2 9}$ & Sakarya Üniversitesi \\
\hline $\mathbf{1 5}$ & Uludağ Üniversitesi & $\mathbf{3 0}$ & Eskişehir Osmangazi Üniversitesi \\
\hline & & &
\end{tabular}

